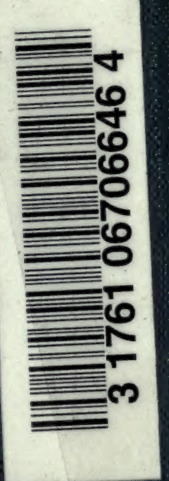

Univ. of Tonowro LIERABY 



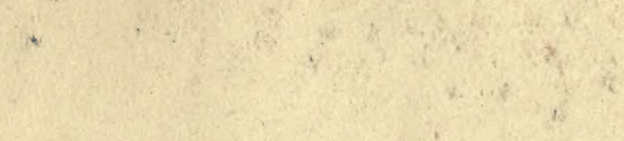




Digitized by the Internet Archive in 2007 with funding from Microsoft Corporation 
ACRIDIIDFE

FRONTISPIECE

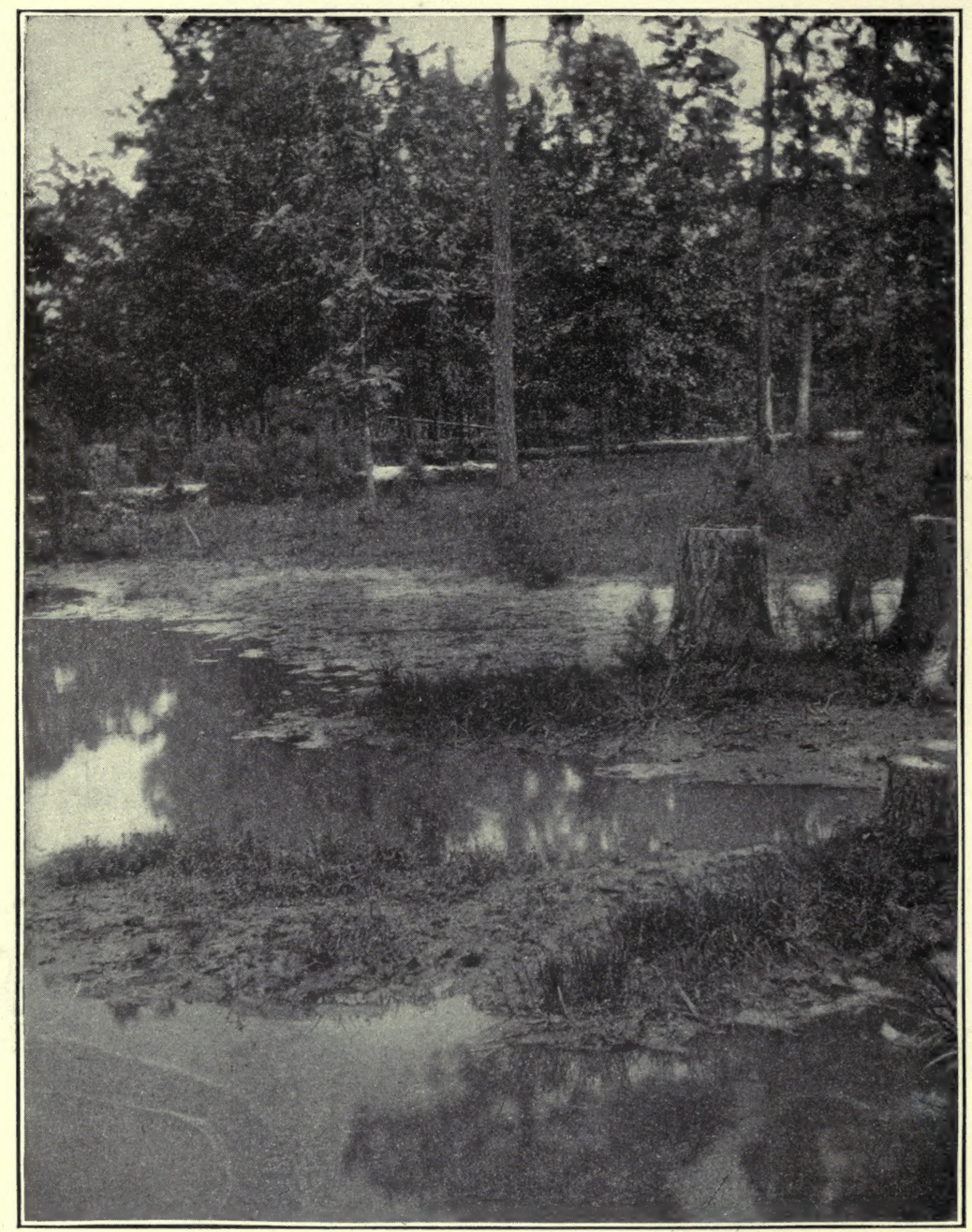

TYPICAL TETTIGIAN HABITAT IN LOWLANDS OF ARKANSAS. ASHDOWN, ARKANSAS. 


\section{FURTHER RESEARCHES}

\section{ON \\ NORTH AMERICAN ACRIDIIDÆ}

BY

\section{ALBERT PITTS MORSE}

Research Assistant, Carnegie Institution of Washington

Curator of Zoological Museum, Wellesley College.

Instructor in Zoology, Teachers' School of Sciences, Boston

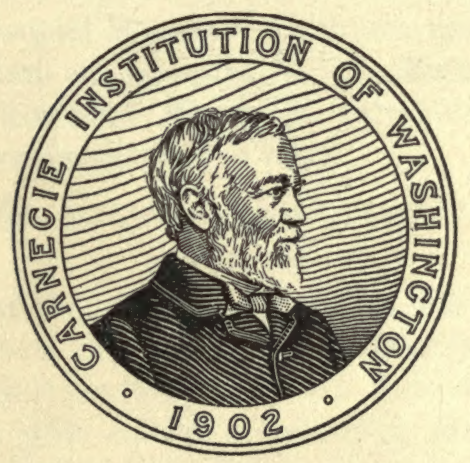

PUBLISHED BY THE

CARNEGIE INSTITUTION OF WASHINGTON

1907

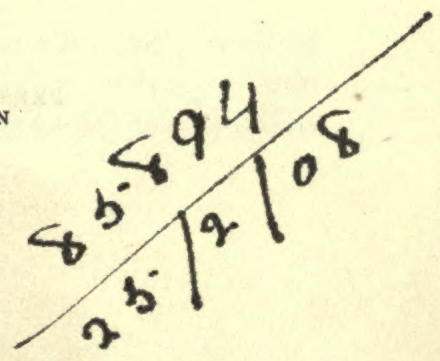




\section{CARNEGIE INSTITUTION OF WASHINGTON}

PUBliCATION NO. 68.

PRESS OF THE, WILKENS-SHEIRY PRINTING CO. WASHINGTON, D. C. 


\title{
FURTHER RESEARCHES ON NORTH AMERICAN ACRIDIIDE
}

\author{
By Albert Pitts Morse, \\ Research Assistant, Carnegie Institution of Washington.
}

\section{INTRODUCTION.}

The following report is based upon data obtained during a second field trip of ten weeks' duration in the summer of 1905 under the auspices of the Carnegie Institution of Washington, and forms a partial field study of the Acridian fauna of the central Southern States. A large amount of material and of biological data and several undescribed forms were secured.

\section{ACKNOWLEDGMENTS.}

To the Trustees of the Carnegie Institution of Washington I wish to express my deep appreciation of the liberality which has enabled me to conduct these investigations. I desire also to express my indebtedness to Drs. B. L. Robinson and M. L. Fernald, of the Gray Herbarium, for the determination of plant specimens; to Mr. A. N. Caudell, of the United States National Museum, for aid in identifying material; to Mr. Samuel Henshaw for favors received in connection with the examination of material in the Museum of Comparative Zoology; and to him and Mr. S. H. Scudder for their unfailing interest and encouragement in this work.

\section{PURPOSE, METHODS, AND OUTLINE OF TRIP. \\ PURPOSE.}

The purpose of the second trip, which was undertaken in continuation of the work of the first, was primarily, like that, to secure general information regarding the North American locust fauna and its ecology over a wide extent of relatively little-studied territory. Such information once secured (as is now the case for the greater part of the country), further effort bearing upon details of taxonomy, distribution, ecology, and variation can be more wisely directed.

\section{METHODS.}

The general information needed can be most effectively secured by a rapid reconnaissance or sampling process, visiting as many points of widely varying physical condition in the territory under examination 
as may be reached in the time available. If possible, sufficient time should be spent in each locality to enable an examination to be made of each kind of locust habitat represented in its vicinity. This will give a good general idea of the locust fauna of that locality and may usually be done in from one to three days of field-work, according to the weather, the character of the locality, the number of habitats represented, their accessibility, etc. This method, however, is often impracticable when it is necessary to cover a large extent of country in a limited time.

OUTLINE OF TRIP.

At the beginning of the season of 1905 it was planned to continue investigations by making a general reconnaissance similar to that of 1903, during the summer vacation, in the next group of States west of those examined in that year, viz, Tennessee, Alabama, Mississippi, Louisiana, and Arkansas. Accordingly, passage was taken July 5 for Chattanooga, via Washington and Cincinnati, in order to secure at first hand, albeit from a car window, some knowledge of the physical conditions with reference to locust habitats which are found in southern Ohio, eastern Kentucky, and Tennessee, a region not previously examined in person.

Collecting was begun on Sand Mountain plateau in the vicinity of Trenton, Georgia, a point visited late in the season of 1903 , in order to secure data, if possible, on those species appearing in the adult stage only early in the season (see fig. I). Other stops were made at Valley Head, Alabama, to visit Lookout Mountain; Anniston, the readiest point of approach to Cheaha Mountain, the highest summit in Alabama, and Tuscaloosa. During this portion of the trip it was learned that the season was very backward, both vegetation and locusts being late in development, probably owing to the excessive amount of cool and rainy weather of the spring months. In consequence of this fact I hastened southward to Gulfport, Mississippi, on the Gulf coast, stopping at Meridian and Hattiesburg en route. After three days spent there and at near-by points the presence of yellow fever in New Orleans was announced, and in the hope of being able to do the work planned for that vicinity and get away before freedom of travel was interfered with, should that difficulty arise, I went immediately to New Orleans and spent one day in the suburbs and another in a trip down-river and back to the marsh region at Buras, the present terminus of the railroad. Learning that if I remained in the city longer there was every likelihood of enforced and probably prolonged delay, I went west to Franklin, with the intention of collecting there 
until a health certificate enabling me to travel freely could be secured. An examination of the country showed that owing to the daily and long-continued torrential rains which characterized the early summer in Louisiana, Arkansas, Texas, and the Territories, effective collecting was impossible in consequence of the semi-inundated condition of the flat country.

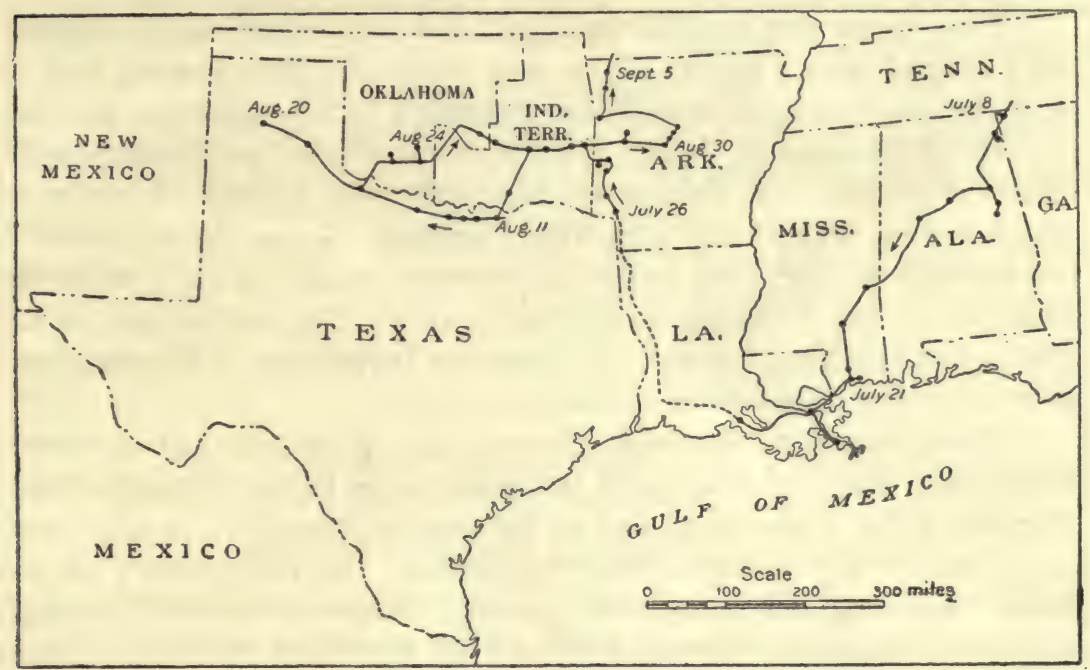

FIG. I. - Sketch map showing route traversed during the season of 1905.

At this juncture I was fortunately able to secure from an authoritative source information of the true magnitude of the fever situation in Louisiana. This was to the effect, as everyone now knows, that the fever had been in the city two months instead of a few days, that nearly roo cases had occurred to date, and that two other points, and probably more, besides New Orleans, were infected. This statement was accompanied with the advice of one experienced in fever quarantines to "get out of the State as soon as you can, if you can." Under the circumstances, in order to avoid prolonged delay under highly unfavorable working conditions and the waste of valuable time and opportunity, it seemed best to act at once upon this advice, which was done forthwith.

Texas and Mississippi having already declared a quarantine against Louisiana, the next day saw me at work in western Arkansas, in which section and the eastern part of the Indian Territory I collected with gond results while awaiting development of the fever situation. Finding that there was no prospect, owing to quarantine restrictions, of 
examining advantageously a large portion of the affected States, which I had intended to study, a change of the original plan became necessary. I decided to spend the remainder of the season in a trip through northern Texas as far as the Staked Plains, and return through Oklahoma and the Indian Territory, visiting the Wichita Mountains en route, and northwestern Arkansas, if practicable, at the end of the trip.

This course was decided upon with the double purpose of examining a district whose locust fauna was relatively little known and of studying the biological conditions presented by the transition between the humid Mississippi Valley and the Great Plains, particularly with reference to the distribution of brachypterous locusts, a study of which during several years in New England, on the Pacific Coast in the summer of 1897 , and in the southeastern States in 1903 under the auspices of the Carnegie Institution, led to the conclusions in my first report (Publication No. I8, Carnegie Institution of Washington) relative to the significance of brachypterism.

Going south to Denison, Texas, this plan was put in effect. Stops were made at Bonita, in the western or Upper Cross Timbers, Wichita Falls, Clarendon, and as far west as Amarillo, on the Llano Estacado, in the center of the Panhandle. At this point I turned back, retracing my course to Quanah, thence northward through southern Oklahoma, paying a brief visit to Mount Sheridan, one of the two highest peaks of the Wichita Mountains. From thence, after a stop at Shawnee and another at Wilburton to examine an interesting bit of prairie meadow noted on the outgoing course, I returned to western Arkansas and visited Magazine Mountain (whose summit is the highest point of land between the Appalachian and the Rocky Mountains), the Arkansas Valley, and the Ozark uplift at Winslow and Fayetteville.

The trip was carried out successfully as outlined, collecting being brought to a close at Fayetteville, Arkansas, with the advent of rainy weather in early September. On the return trip to Wellesley, a day's stay at Indianapolis with Prof. W. S. Blatchley, State geologist, who has made a special study of the Orthoptera of that State, and another spent in a visit to the collection of Orthoptera at the National Museum, in charge of Mr. A. N. Caudell, proved most profitable.

Over 9,000 Orthoptera, of which the great bulk are Acridiidæ, representing about 20 species, including several undescribed forms, were secured, together with a mass of data relating to distribution and biology. 
LIFE ZONES OF REGION EXAMINED.

The region examined lies entirely within the Austral life zones, between the parallels of $29^{\circ} 20^{\prime}$ and $36^{\circ} \mathrm{ro}^{\prime}$. The highest mountain summits visited-Cheaha Mountain, Alabama, 2,400 feet; Magazine Mountain, Arkansas, 2,800 feet; Mount Sheridan, Oklahoma, 2,500 feet, and the Great Plains at Amarillo, Texas, 3,60o feet-do not reach an altitude sufficiently high to provide boreal conditions, but show traces of a Transition element. The Upper Austral zone was studied on the highlands of northeastern Alabama, western Arkansas, the Wichita Mountains of Oklahoma, and at Amarillo. The Gulf strip of the Lower Austral was touched at three points in southern Mississippi and the same number in Louisiana.

Wichita Falls, Texas; Cache, Oklahoma, and localities west of those points lie in the arid or Sonoran division of the Austral zones. This section is, however, more strictly semi-arid than arid in character, when compared with the extreme arid region of southwest Texas, New Mexico, Arizona, etc.

At present it is impossible to state with certainty which species are characteristic of each of these zones and districts.

HUMID AND ARID FAUNAS, DISPERSAL, BRACHYPTERISM.

Two of the chief biological points upon which it was desired to secure information in the region visited were in reference to the status of brachypterous species in treeless districts,. and the transition between the faunas of the humid and arid parts of the Austral zones. Based upon the data secured on this trip, it would appear that as a whole the biota of the treeless plains and prairies is characterized by an Acridian fauna richer in number of species than that of the East, and that these are of geophilous and campestrian character in consonance with the climate and the habitats represented. While differing much in general facies from that of the Eastern States of the same latitude in these particulars, the transition from humid to arid conditions and fauna is gradual rather than abrupt,* the borderland of the two in Texas, Indian Territory, and Oklahoma being peopled by numerous genera and species of very wide, in some cases transcontinental, distribution, and also by some of more limited range restricted to the district between the Mississippi River and the Rocky Mountains, but occurring both in the humid and arid sections of this region.

Dispersal of the xerophile, arid-land species is doubtless chiefly effected through the agency of the winds, especially the strong sonth-

*Possibly this conclusion may need qualification after more detailed study. 
erly summer winds; frequent tornadoes (northeast), and débris-bearing river floods (east and southeast). Dispersal being thus amply provided for, colonization or permanent extension of range is dependent on the conditions (chiefly chemical and physical) affecting the physiological welfare of the accidental or intentional migrant.*

Brachypterous species are much less numerous proportionally in the treeless arid districts than in humid, forested regions, East or West. When present, they inhabit shrubby or herbaceous thickets. It is a noteworthy fact that (excluding the aberrant group Tettiginæ) every flightless species of locust known from the eastern half of the continent is phytophilous, as distinguished from geophilous, in habits.

\section{LOCUST COLORATION.}

In consideration of certain misapprehensions as to the biological significance of the colors borne by the Acridiidæ, a few general state: ments regarding the coloration of these insects will not be amiss.

The Acridiidæ exhibit both structural and pigmentary colors. An example of structural color is the iridescence of the wing membranes, shown especially well in the Tettiginæ, some Melanopli, and other species with transparent wings. All the other colors are pigmentary in character, at least in part, and doubtless originate in the life-processes of the body. Those of sympathetic character-i. e., resembling the environment-are in many cases, e. g., among desert species, perhaps originally physiologically protective in function, as suggested by Gadow for reptiles; the exposed non-sympathetic colors probably possess a biological significance varying with the position and use of the organs on which they are displayed.

A locust presents three classes of surface with reference to coloration: Ist, the ventral part of the body next its supporting surfaceearth or plant-which is shielded to a great extent from external influences such as the action of light, etc., and the observation of birds and other enemies; $2 \mathrm{~d}$, those parts continually exposed, day and night, at rest and in action, to the influences above-mentioned, comprising the dorsal, lateral, anterior and posterior surfaces; $3 \mathrm{~d}$, those parts exposed only occasionally, and usually for brief periods only, during attack, courtship, or other exciting circumstances, or while in rapid motion, comprising the wings, hind tibiæ, inner and under sides of hind femora, and sides of base of abdomen.

*The presence or absence of a given species in a locality is largely dependent on the character of the habitats represented. If woodland is lacking, sylvan species are absent; if ledges or similar rock surfaces are not at hand, saxicolous species will not be found. 
The coloration of each of these surfaces needs to be studied in correlation with that of the others and with direct observations on the habits and distribution of the insects in the field. That of the first class of surfaces has received scant attention, much less than it deserves. It is probably chiefly physiological in character. That of the second class is, with few exceptions, highly sympathetic, harmonizing or resembling very closely, often to a marvelous degree, the background of the creature's environment. Earth tints, rock and sand textures, the infinitely varied browns, greens, and grays of living and dead vegetation, yellow, orange, rose, and silvery white are all represented, in spots and streaks, the effect being to merge the insect indistinguishably in its background while at rest, thus shielding it in a very high degree from the observation of its foes. These colors are of very great protective value at the present time, natural selection continually acting to preserve and perfect them, but, though highly protective in character, they are without doubt primarily due to physiological processes and influences as yet imperfectly understood.

The colors of the third class of surfaces are, on the contrary, in many cases non-sympathetic in character to a high degree; they are often bright and strongly contrasted, striking in effect and at times exceedingly conspicuous. This is very generally the case among the North American Oedipodinæ and certain Acridiinæ. What is the function, the significance of these colors, in these places, seen only in flight or when especially displayed? Let us consider the color of the wings first.

Vosseler, in his most important work (Zool. Jahrb., Abh. f. Syst., Bd. I6, I7), misled by the natural-selection theory, tries mistakenly to apply it to this kind of wing-coloration, assigning to these colors a protective value through "contrast-mimicry" by a dazzling of the pursuer through their sudden appearance and disappearance. As a matter of fact, in American species at least, these colors are usually exposed continuously during flight.

This explanation is a needless tax upon the imagination. There is a much simpler one which is almost forced upon the attention of the stroller in the fields, and which may be readily observed by taking a favorable position in a station thickly populated with adult Trimerotropis, Arphia, Spharagemon, Hippiscus, Dissosteira, or other similarly decorated Oedipodinæ.

The flight of one of these locusts attracts attention by its crepitating character; the conspicuous wing-colors, red or yellow and black, in strong contrast, render its flight easy to follow, as it is very frequently followed, by others, which drop to the ground in close 
proximity to it. There can be no doubt in the mind of one who has watched these actions repeated over and over again, of the value of these colors as a means of signaling, of attracting attention, and thereby effecting or maintaining communication between the sexes or the individuals of a community.

The wing-colors are also frequently displayed during courtship, while the insect is at rest upon the ground or a suitable perch, and even when attacked by enemies. Such is the case in Dictyophorus and Brachystola.

The colors of the hind tibir and inner sides of the hind femora, though often bright, are too limited in extent of surface to be of use as a signal during flight. They are entirely hidden when the insect is at rest, but come into view while it is walking and during the stridulatory movements of the hind legs which most Acridiidæ practice in mating-time. These conspicuous non-sympathetic colors, displayed only at such times, thus seem to possess a direct sexual significance.

The wing and tibial colors differ much, not only specifically, but also individually in the same species, frequently varying, on the tibiæ, from clear yellow to red, sometimes deeply infuscated, or from red through yellow and greenish to deep blue, on the wings from pinkish red through orange to yellow and yellowish-white.

Bruner (Science, XXI, I33) noted an apparent relation between the coloration of the wings and the degree of humidity of the climate. Morse (Psyche, virr, 7) suggested that temperature should also be considered in this connection. Hart in a recent paper (Bull. Ill. State Lab. Nat. Hist., vII, art. vir, pp. $2 \mathrm{I}_{4}$ et seq.) has collected data indicating a similar relation of the tibial colors to humidity. As stated by Bruner and Hart, a blue coloration of wings and hind tibiæ seems to be associated with a certain degree of aridity of climate, a red coloration with humidity.

There is reason to think, however, that several factors are concerned in this variation of color. Pigmental in character, originating in the life-processes of the body, these colors are undoubtedly sensitive to whatever affects the metabolism of the organism, as well as to external agencies. Moisture and temperature, it is possible, play the chief part as factors in this color-variation, but it is quite likely that altitude or atmospheric pressure, character of food, and quality of light are concerned in these phenomena, with reference to the Acridiidæ at least, despite the negative results noted by Tower in reference to Leptinotarsa, a genus of beetles (Carnegie Institution of Washington Publication No. 48). 
Certainly, if there is a tendency on the part of the organism to assume a coloration resembling that of the environment apart from natural selection through protection from enemies, then we should expect a variation in color correlated in some way with the character of the light rays in different climates, at high altitudes (cf. alpine flowers), on the seabeach, in grassy fields, or sylvan thickets.

As yet, however, I am forced to believe that sufficient data of adequate weight have not been accumulated to provide a satisfactory explanation of this color-variation of the wings and hind tibiæ. It is a matter with regard to which evidence should be specially collected by careful field observations, by critical study of closely related forms and of climatic data from different sections of the country, and by experimentation if possible.

\section{NOTES ON COLORATION AND VARIATION.}

As will be readily understood, the character of the trip forbade the payment of much attention to problems of variation or the acquisition of material in sufficient series for statistical study. The subjoined notes are presented as suggestions for those having opportunity to make observations on this topic in connection with the species involved and as a basis for future work.

Excellent examples of coloration agreeing with that of the environmental background are presented by Hypochlora alba and Trimerotropis saxatilis (pl. I).

The habitat of the former is upon several species of sage (Artemisia) pale greenish-white in color, and the locusts inhabiting it, young and old, are of the same tint. The photograph shows the striking contrast with customary hues exhibited by these plants.

In the latter species specimens from the same station vary widely from light to dark in agreement with the hues of the lichened rocksurfaces frequented. Variations of ground-color also occur geographically, examples from the Wichita Mountains exhibiting a flesh-color like that of the ruddy, weather-beaten granite on which they live. It seems highly probable that this relatively sluggish, unwary species (see p. 40) has escaped destruction only by reason of its highly developed protective coloration. Existing, as it now does, only in isolated colonies, in habitats of highly special character, which continually diminish in area through various physical and organic agencies, it is not unlikely that in the comparatively early future it will become extinct.

Noticeable color-variations, as yet unexplained, are also presented by the specimens of Melanoplus fasciatus and $M$. bivittatus femoratus (see p. 47) secured in Alabama, as compared with northern examples. 
As nearly as may be judged from the limited material at hand, several so-called species of Trachyrhachis founded largely upon colorcharacters (thomasi, fuscifrons, obliterata, kiowa) are to be regarded simply as geographical varieties or races of a widely spread species varying with the climatic environment. Thus, $T$. thomasi, the form inhabiting the more eastern and humid section of its range (Georgia, Tennessee, Illinois, Arkansas, Indian Territory), possesses wings with a complete, rather broad, transverse fuscous band and lemon-yellow disk; fuscifrons, from more western and less humid localities in Texas and Oklahoma, exhibits a narrower, usually broken wing-band and yellow disk, the latter sometimes nearly hyaline; in obliterata the wing-band is reduced to faint cloudings in the radial and posterior parts of its course or is frequently lacking (this form is found in the semi-arid parts of central and western Texas and Oklahoma); kiowa, lacking the wing-band entirely and with hyaline disk, is the characteristic form at Amarillo on the Staked Plains. We apparently have in this instance another case of increased development of pigment correlated with humid conditions. Further observations should be made on material in large series. (See also p. 37.)

Variation in color and structure geographically along the lines of probable dispersal and descent is exhibited by Hesperotettix pratensis. Examples of this species from Magazine Mountain, Arkansas, are shorter-winged than plains specimens and exhibit almost exactly the type of coloration shown by $H$. brevipennis. The specimens of the latter species from Georgia and Alabama approach in size, winglength, and color the Arkansas examples of pratensis. It is probable that complete intergradation will be found to exist, and that $H$. brevipennis is the eastern representative of pratensis, directly descended and not specifically distinct from that species. The Florida examples of $H$. pratensis secured in 1903 , on the other hand, present a distinctly different type of coloration-one seen in some Californian series of the species. They are also of small size like them, but differ in having much longer tegmina and wings. H.pratensis, as it stands to-day, should be regarded as a variable and complex species represented in different parts of the country by several more or less distinct varieties.

The same phase of variation (along the line of dispersal and descent) is probably the explanation of the striking difference shown in examples of Trimerotropis saxatilis from Stone Mountain, Georgia, and Mount Sheridan, Oklahoma. But for the intergrades from Arkansas and identity of habits these two forms would be regarded as specifically distinct on the basis of structural characters. In this case Trimerotropis vinculata, very widely distributed in the far west, is probably the parent species. 


\section{HABITS, HABITATS, AND LOCAL LISTS.}

As has been stated, the work of collecting began in northwest Georgia, at a point visited toward the end of the first trip, in the hope of securing early-maturing species not procurable at that time, particular attention being paid to the fauna of the Sand Mountain plateau, at an elevation of $I, 500$ feet. Here the following species were secured in the adult state:

Nomotettix cristatus.

Neotettix femoratus.

Tettix arenosus.

Tettigidea lateralis.

Syrbula admirabilis.

Eritettix carinatus.

Orphulella pelidna.

Arphia sulphurea.

Hippiscus phoenicopterus.
Dissosteira carolina.

Spharagemon bolli.

Trimerotropis saxatilis.

Hesperotettix brevipennis.

Melanoplus atlanis.

Melanoplus bivittatus femoratus.

Melanoplus impudicus.

Melanoplus strumosus.

Of these the only ones calling for particular mention are Melanoplus strumosus, discovered in Florida on the first trip, whose presence so far north was unexpected; and Trimerotropis saxatilis, notes on whose habits will be found in the accompanying list of species (page 39; p1. I, fig. 2). At Trenton, on the floor of Lookout Valley, at an elevation of about 735 feet, Schistocerca americana, Trimerotropis citrina, and the young of Hippiscus rugosus were also secured. Here also, thanks to information received from Mr. J. T. Woolbright, an observing resident, a colony of Dictyophorus reticulatus, the great southern "lubber grasshopper," was located far to the north of its supposed range. Other species, at this time in the young stages, taken at this point on the first trip, are Amblytropidia occidentalis, Arphia xanthoptera, Chortophaga viridifasciata, Trachyrhachis thomasi, Melanoplus femur-rubrum, and $M$. luridus. The following species in addition undoubtedly occur in the vicinity : Tettix ornatus, Paratettix cucullatus, Dichromorpha viridis, Schistocerca alutacea and rubiginosa, Melanoplus scudderi, and probably several other short-winged species of this genus. These species may be regarded as a fair sample of the locusts most likely to be secured in northern Alabama in July.

Of these, Trimerotropis saxatilis is a purely saxicolous species restricted to bare rock surfaces. Dissosteira carolina and Trimerotropis citrina are to be found on roads and spots of bare soil; Trachyrhachis thomasi also frequents bare soil and sparsely grassed fields, but is much less common and very local. Amblytropidia occidentalis, Syrbula admirabilis, Chortophaga viridifasciata, and the species of Arphia and 
Hippiscus occur in old fields and pastures on dry soil, where the grass is tall and interspersed with bushes. Several of these, together with Spharagemon bolli, Melanoplus impudicus and luridus, live in the open forest, generally near grassy places. Schistocerca americana is almost ubiquitous, among vegetation of all sorts. Melanoplus atlanis prefers dry, grassy fields; $M$. femoratus moist runs, the banks of streams, etc.; $M$. femur-rubrum damp, grassy fields; and $M$. strumosus the undergrowth of woods. Hesperotettix brevipennis has been taken only on bunch-grass (Andropogon), either in fields or openings in the forest. The Tettiginæ, with the exception of Tettigidea lateralis from moist, sedgy runs, prefer somewhat exposed but rather moist soil of sandy loam or the banks and beds of streams.

From Valley Head, Alabama, the next stopping-place, the summit of Lookout Mountain was paid a brief visit, for the purpose of comparison. At the point reached, the locust fauna was very similar to that on Sand Mountain, but perhaps less numerous in species and individuals.

Anniston, in the east-central part of the State, was chosen as the most convenient point of approach to Cheaha Mountain, the highest summit in Alabama. Immediately about Anniston the collecting was decidedly and inexplicably poor, both in species and individuals. Twenty miles south, at Turnipseed's ranch near the foot of Cheaha, a rich collecting spot was found, but only a very limited stay could be made there. Several hours were spent on the summit of Cheaha $(2,000$ to 2,400 feet) between Pulpit Rock and the top, and important results were secured.

The summit crest is covered with an open, stunted, fire-scarred forest of oak and other deciduous trees, xerophytic in character, with scattered boulders and occasional outcrops, a rank growth of bunchgrass, and occasional shrubby patches. While not of sufficient elevation to reach a distinctly boreal zone, and too limited in area to greatly modify the temperature of the air passing over it, here was found a most interesting aggregate of species, as follows:

Mermiria bivittata.

Orphulella pelidna.

Orphulella speciosa.

Arphia sulphurea.

Hippiscus phoenicopterus.

Dissosteira carolina.

Spharagemon bolli.

Schistocerca alutacea.
Hesperotettix brevipennis.

Melanoplus impudicus.

Melanoplus viola.

Melanoplus fasciatus.

Melanoplus bivittatus femoratus.

Melanoplus tribuloides (new species).

Podisma australis (new species). 
Most of these call for no particular remark, but Orphulella speciosa, Melanoplus bivittatus femoratus, and $M$. fasciatus are Transition and slightly boreal in character, and in this region are to be regarded as glacial relicts. Of the two new species, $M$. tribuloides is a near relative of a species found at a slightly greater elevation on the neighboring mountains of Georgia; the other is a new and wholly unexpected species of Podisma, bearing tegmina of considerable size, and resembling Dendrotettix in some characters.

At Tuscaloosa, the next point visited, in the western part of the State, nothing of importance was found to call for special remark. At all points thus far examined, the young of many species far outnumbered the adults, owing, probably, to the late season. Consequently, as I expected to visit the northern part of the State late in the summer, I hastened southward. At Meridian, Mississippi, a new shortwinged Melanoplus allied to obovatipennis (common in Indiana and Arkansas), doubtless its southern representative, but presenting considerable difference in color and structure, was secured. At Hattiesburg, Melanoplus viola was taken in some numbers, and a single pair of $M$. morsei, greatly extending the known range of this species from Indiana southward.

Gulfport, on the coast, served as a center for an examination of the Coast strip, collections being made in the town, eastward at Biloxi, and inland as far as Nugent. A list of actual captures of the species here follows, though several others might be cited as inhabitants in addition :

\footnotetext{
Neotettix femoratus.

Paratettix cucullatus.

Tettigidea lateralis.

Mermiria bivittata.

Syrbula admirabilis.

Amblytropidia occidentalis.

Orphulella pelidna.

Orphulella olivacea.

Clinocephalus elegans.

Arphia xanthoptera.

Chortophaga viridifasciata.
}

\author{
Hippiscus phoenicopterus. \\ Hippiscus rugosus. \\ Scirtetica picta. \\ Psinidia fenestralis. \\ Trimerotropis citrina. \\ Leptysma marginicollis. \\ Schistocerca alutacea. \\ Schistocerca americana. \\ Melanoplus propinquus. \\ Paroxya atlantica. \\ Paroxya floridiana.
}

Of these species, Orphulella olivacea, Clinocephalus elegans, Scirtetica picta, Melanoplus propinquus, and Paroxya atlantica are characteristic of the coast region, $O$. olivacea being restricted to salt-marshes, the others extending inland for some distance. Scirtetica picta, Trimerotropis citrina, and Psinidia fenestralis are usually found on the sands of the upper beach and in sandy spots near it. Paroxya floridiana 
occurred with Orphulella olivacea in the speargrass of the marshes. Paroxya atlantica occurs in the marshes also, but was more common locally in the pine woods, in moist grassy spots among the "inkberry" or myrtle bushes (Ilex glabra). (P1. 2, fig. 2.)

The piney woods present two general types of habitat, wet and dry, but owing to the low relief of the face of the country a very mixed condition occurs, xerophile and hygrophile species seemingly all jumbled together. In low spots, swampy places and along streams, may be found Leptysma marginicollis, Tryxalis brevicornis, and Clinocephalus elegans. On the drier, sandy, more open spots will be met Arphia, Hippiscus, Neotettix, Orphulella, and Psinidia. Mermiria bivittata is found only among coarse grasses, in either wet or dry situations. (P1. 2, fig. I).

As has been stated in the outline of the trip, collecting in Louisiana was perforce abbreviated by the imminence of interference with travel owing to the outbreak of yellow fever.

In the vicinity of New Orleans a brief time was spent in the field between showers at Milneburg, on the edge of the swamp. Here Dictyophorus reticulatus was found in numbers, and a single very large example of Paroxya hoosieri, not previously known from south of Indiana. A trip 60 miles down-river and back to Buras, in the marsh region, occupied one day. The two species most in evidence at this point were Chortophaga viridifasciata, numerous on the higher ground near the levee, and Orphulella olivacea, widely and generally spread in the marshes in company with Orchelimum herbaceum. At Franklin, owing to the flooded condition of the country, it was impossible to collect to advantage except along the railway embankment, and but half a dozen species were secured. At this point the eastern and southern part of the trip closed.

Arkansas was visited in its western part only, between the dates July 26 to August 3 and August 28 to September 5. The earlier period was spent in the southwestern part of the State-at Ashdown, in the lowlands; DeQueen, in rolling country; Mena, Eagleton, and Rich Mountain Station at the foot of Rich Mountain; and on the summit of Rich Mountain, at an elevation of 2,600 feet. At this earlier period many species were still immature in the mountain region. During the latter period collections were gathered at Blue Mountain Station and the summit of Magazine Mountain, Ola, Dardanelle, and Van Buren, in the Arkansas River Valley; Winslow, high up on the Ozark uplift; and Fayetteville, in the hill country of the extreme northwest. 
At Ashdown, in the lowlands of the southwest corner of the State, the following species were secured in the adult stage :

\author{
Neotettix femoratus. \\ Tettix arenosus. \\ Paratettix cucullatus. \\ Tettigidea lateralis. \\ Syrbula admirabilis. \\ Orphulella picturata. \\ Orphulella pelidna. \\ Dichromorpha viridis.
}

\author{
Arphia xanthoptera. \\ Chortophaga viridifasciata. \\ Hippiscus rugosus. \\ Spharagemon bolli. \\ Trimerotropis citrina. \\ Schistocerca obscura. \\ Melanoplus bispinosus. \\ Paroxya sp.
}

All of these are found east of the Mississippi River except twoOrphulella picturata and Melanoplus bispinosus-which are transMississippian in distribution, common on the prairies from central or western Arkansas to Oklahoma. In the lowlands of Arkansas, as has been noted in reference to other regions of low relief in the southeastern States, typical xerophile and hygrophile locusts occur in many places side by side in consequence of the topographical configuration. No particular features of locust distribution or habitat at Ashdown call for special remark, save the exceeding abundance of Tettiginæ, the continually moist sandy loam of the locality seeming especially favorable to the development of great numbers of this group of locusts (see frontispiece).

The fields of a great part of Arkansas are carpeted with the creeping, purple-flowered Japanese clover (Lespedeza striata), or, in the more open stretches, are covered in late summer with a dense growth of the fine-leaved sneeze-weed (Helenium tenuifolium) and yellow with its brilliant blossoms. While a few species of locusts (Dichromorpha viridis, Chortophaga, Orphulella) are found more or less commonly in this habitat, it is as a whole less productive than grassy nooks and corners, or fields partly bare and partly grown up to taller weeds and bushes, in short, presenting a greater variety of environment.

The mountains of Arkansas form two groups-the Ouachita ranges south of the Arkansas River and the Ozark plateau north of it. The Ouachita Mountains consist chiefly of several irregular but often eastand-west extending ranges, which for the most part still retain their forest covering. The southern slopes, owing to greater insolation, are very hot and dry, the forest is xerophytic in character and quite open (pl. 3, fig. 2). Characteristic of this habitat are Spharagemon bolli, Melanoplus obovatipennis, scudderi, keeleri, robustus, Boöpedon auriventris, and Paratylotropidia brunneri. The first five of these are common and widely distributed, the latter two are local and scarce. 
The north side of these ranges is much moister, more densely shaded, its plant covering more boreal, and altogether presents a very different environment from the southern side. At a station of this character on the north side of Magazine Mountain, almost in the shadow of the summit escarpment, in an herbaceous thicket composed largely of Urtica gracilis, Polygonum virginianum, Amphicarpoea monoica, Eupatorium ageratoides and Solidago sp. was found Melanoplus gracilis, whose delicate olive coloration exactly matched the background of its haunts, so widely at variance with that of the opposite side of the mountain summit. Continued search in other localities of this character would probably reveal additional species characteristic of this type of habitat.

The higher summits of the mountains rise to an elevation of but 2,400 to 2,600 feet, Magazine or Blue Mountain reaching 2,800 at one point and being the highest point of land between the Appalachian and the Rocky Mountains. This elevation is not sufficient to provide true boreal conditions, but does modify the temperature so that certain species, abundant at the north, and forced southward during the glacial epoch, have been enabled to exist in this latitude till the present time. Such are Tettix hancocki, Chloëaltis conspersa, and Melanoplus fasciatus (= baconi of McNeill).

The two summits of the Ouachitas visited, Rich Mountain and Magazine Mountain, differ very noticeably in the relative abundance of the two common campestrian species Melanoplus atlanis and femurrubrum, which are plentiful on the first, scarce on the second. This difference is no doubt due primarily to the fact that the summit of Rich Mountain was for many years the site of prosperous farms, now abandoned and rapidly reverting to original conditions (p1. 3, fig. I). The summit of Magazine Mountain, on the other hand, has been much less disturbed by cultivation, and the forest covers a great part of it. The flat top of this mountain is bounded by an almost continuous escarpment, the rock being commonly exposed at the level margin and forming an ideal habitat for Trimerotropis saxatilis (p1. 4, fig. I). At the extreme west end of the summit, where the roadway climbs it, and where a small area has been recently cleared of trees, an interesting assemblage of species was found among the golden-rod, blueberries, grass, and shrubby sprouts that have sprung up (p1. 4, fig. 2). Here were taken Trimerotropis saxatilis, Hesperotettix pratensis, Boöpedon auriventris, Paratylotropidia brunneri, Melanoplus scudderi, $M$. obovatipennis, Hippiscus phoenicopterus, Spharagemon bolli, Schistocerca rubiginosa, Orphulella pelidna, and several others, some of them in numbers. 
The explanation of this assemblage probably involves several factors : primarily, variety of habitat represented-rock, bare soil of sandy road, grass, shrubby undergrowth ; secondarily, aggregation of individuals at a topographical "jumping-off place," a phenomenon akin to the assembling of many other insects at the extreme apex of a high hill or mountain summit, which has been repeatedly observed.

Besides the two prairie species previously mentioned as captured at Ashdown, several others occur in at least the western part of the State. Among these are Orphulella decora, Campylacantha olivacea and its color-variety acutipennis, and Melanoplus foedus. Orphulella decora lives in grassy fields, by preference of moister character than those inhabited by picturata; Campylacantha olivacea, a short-winged species, is locally common in herbaceous thickets of various kinds, but commonly of some species of ragweed (Ambrosia bidentata et al.).

The following list of species captured in western Arkansas is here brought together for convenience of reference; several others occur and would be secured by a longer search and at other seasons of the year :

\author{
Nomotettix cristatus. \\ Neotettix femoratus. \\ Tettix arenosus. \\ Tettix hancocki. \\ Paratettix cucullatus. \\ Tettigidea armata. \\ Tettigidea lateralis. \\ Tettigidea lateralis polymorpha. \\ Syrbula admirabilis. \\ Amblytropidia occidentalis. \\ Orphulella decora. \\ Orphulella pelidna. \\ Orphulella picturata. \\ Dichromorpha viridis. \\ Chloealtis conspersa. \\ Boöpedon auriventris. \\ Arphia sulphurea. \\ Arphia xanthoptera. \\ Chortophaga viridifasciata. \\ Hippiscus phoenicopterus. \\ Hippiscus rugosus. \\ Dissosteira carolina. \\ Spharagemon bolli.
}

Trachyrhachis thomasi.
Trimerotropis citrina.
Trimerotropis saxatilis.
Schistocerca alutacea.
Schistocerca americana.
Schistocerca obscura.
Schistocerca rubiginosa.
Campylacantha olivacea.
Hesperotettix pratensis.
Paratylotropidia brunneri.
Melanoplus atlanis.
Melanoplus bispinosus.
Melanoplus differentialis.
Melanoplus femur-rubrum.
Melanoplus foedus.
Melanoplus gracilis.
Melanoplus impudicus.
Melanoplus keeleri.
Melanoplus latens.
Melanoplus obovatipennis.
Melanoplus robustus.
Melanoplus scudderi.
Paroxya sp.

Trachyrhachis thomasi.

Trimerotropis saxatilis.

Schistocerca alutacea.

Schistocerca anericana.

Schistocerca rubiginosa.

Campylacantha olivacea.

Hesperotettix pratensis.

Paratylotropidia brunneri.

Melanoplus , atlanis.

Melanoplus differentialis.

Melanoplus femur-rubrum.

Melanoplus foedus.

Melanoplus gracilis.

Melanoplus impudicus.

Melanoplus keeleri.

Melanoplus latens.

Melanoplus obovatipennis.

Melanoplus scudderi.

Paroxya sp.

Collecting in Indian Territory was begun on August 4 at Howe, in the eastern part, and continued until August 9; on the return from Oklahoma, a half day was spent at Wilburton on the $27^{\text {th }}$ in examination of a small prairie meadow at that place. 
The eastern part of the Territory and northeast Texas are similar in topography, habitats, and fauna to western Arkansas, and the same species are met with under the same conditions. As one proceeds west from Arkansas through the Territory and Oklahoma, or through Texas, a decrease takes place in the number of eastern, hygrophilous and sylvan species met with, and at the same time a much greater increase occurs in the number of species characteristic of the prairies and plains, xerophile and campestrian in habits and Sonoran in affinities. This may be seen at Caddo and Denison by comparison of the fauna of the wooded strips and of the prairies near these localities.

Among the earliest species to diminish in number and disappear are Dichromorpha viridis, Orphulella pelidna, Spharagemon bolli, Melanoplus robustus and keeleri. Among those that appear earliest in traveling westward in addition to those already mentioned as occurring in Arkansas are Phoetaliotes nebrascensis and Melanoplus plebejus in moist, grassy field-thickets; Arphia luteola and simplex, and Encoptolophus parvus in drier fields ; Ageneotettix deorum and Hadrotettix trifasciatus on bare, stony, or sandy areas; Hypochlora alba occurs locally on white sage (Artemisia spp.; p1. I, fig. I); Opeia obscura lurks in the dense cover of the mesquite grass, together with increasing numbers of Trachyrhachis fuscifrons and Orphulella picturata; Mermiria neomexicana appears and with bivittatus inhabits the taller bunch-grasses (Andropogon, Chrisopogon, etc.). Especially characteristic of loose sand, such as occurs at Bonita, in the Upper Cross Timbers, and locally everywhere, are Spharagemon cristatum and Psinidia fenestralis.

The locust fauna of the dry prairies and lower plains, the " prairieplains" or semi-arid portion of the Texas region, was studied at Wichita Falls, Quanah, and Clarendon, Texas, and Mountain Park and Cache, Oklahoma. The list of species taken at these localities between August 15 and 25 is as follows:

\footnotetext{
Paratettix cucullatus.

Mermiria bivittata.

Mermiria neo-mexicana.

Syrbula admirabilis.

Eritettix sp.

Opeia obscura.

Amphitornus bicolor.

Phlibostroma quadrimaculatum.

Orphulella decora.

Orphulella picturata.

Ageneotettix deorum.

Aulocara elliotti.

Aulocara femoratum.
}

Boöpedon nubilum.

Arphia xanthoptera.

Arphia nietana.

Arphia luteola.

Chortophaga viridifasciata.

Encoptolophus costalis.

Encoptolophus parvus.

Hippiscus corallipes.

Hippiscus immaculatus.

Hippiscus rugosus.

Hippiscus saussurei.

Leprus wheeleri.

Dissosteira carolina. 
Dissosteira longipennis.
Spharagemon aequale.
Spharagemon cristatum.
Trachyrhachis fuscifrons.
Psinidia fenestralis.
Hadrotettix trifasciatus.
Trimerotropis citrina.
Trimerotropis latifasciata.
Trimerotropis saxatilis.
Trimerotropis vinculata.
Trimerotropis bruneri.
Brachystola magna.
Schistocerca albolineata.
Schistocerca americana.
Schistocerca lineata.
Schistocerca obscura.
Hypochlora alba.
Campylacantha olivacea.
Hesperotettix speciosus.
Hesperotettix viridis.

Aeoloplus regalis.

Melanoplus atlanis.

Melanoplus bispinosus.

Melanoplus bivittatus.

Melanoplus differentialis.

Melanoplus femur-rubrum.

Melanoplus foedus.

Melanoplus keeleri.

Melanoplus glaucipes.

Melanoplus flavidus.

Melanoplus impiger.

Melanoplus packardii.

Melanoplus palmeri.

Melanoplus plebejus.

Melanoplus regalis.

Melanoplus tuberculatus.

Phoetaliotes nebrascensis.

Dactylotum pictum.

The high plains, Staked Plains, or, in Texan phraseology simply " the Plains," were touched at but one point, Amarillo, in the center of the Panhandle region of Texas, at an elevation of 3,600 feet, on August I9 and 20. Here the following six species, not taken elsewhere, were secured, together with 25 of the preceding list, many others of which, it is probable, occur there and would have been found in a longer stay :

Cordillacris crenulata.

Trachyrhachis kiowa.

Metator pardalinum.
Tropidolophus formosus. Melanoplus discolor.

Melanoplus lakinus.

Of these species inhabiting the semi-arid plains and prairies Paratettix cucullatus, Encoptolophus parvus, and Trimerotropis citrina frequent the margins or partly dried beds of streams and sloughs or sinks; $E$. parvus is partial to plowed fields also, and $T$. citrina, its congeners, and the species of Dissosteira, Spharagemon, Mestobregma, and Hadrotettix are common on roadsides, washes, ant-fields, and other patches of bare, sun-baked soil, flying up by the dozen before the traveler (pl. 5, fig. I). The low but often dense and tangled growth of mesquite and grama grasses (foreground, pl. 5, fig. 2; p1. 7 , fig. I) is the home of Opeia obscura, Amphitornus bicolor, Cordillacris crenulata, Phlibostroma quadrimaculatum, Orphulella picturata, and Encoptolophus costalis. This habitat is one of those frequented by the species of Arphia and Hippiscus, which also occur in the tall, coarse bunch-grasses in company with the species of Mermiria, Syrbula admirabilis, Phoetaliotes nebrascensis, and several species of Melanoplus. 
Patches of weeds (Ambrosia, Euphorbia, Grindelia, etc., p1. 5, fig. 2, middle distance; p1. 6, fig. 2, foreground) give shelter or sustenance to Aeoloplus, Melanoplus differentialis, and several other species of this genus and of Schistocerca and Hesperotettix; while the tall sunflowers of gulches and waste corners form favorite perches for the huge and sluggish lubber or buffalo hopper (Brachystola magna).

The Wichita mountains form a considerable tract of rugged country of low elevation near the center of southern Oklahoma and represent the summits of an ancient mountain range formerly of much greater elevation and continued eastward in the Arbuckle and other ranges in Indian Territory and western Arkansas, but now almost submerged beneath the accumulation of flood-wash material forming the prairieplains at their base. Some are of rounded contour with grassy slopes, others present summits of bare, sun-scorched crags and boulders nearly devoid of vegetation and jutting suddenly upward from the level plain (p1. 7, fig. I). Tracts of open forest clothe many of the higher slopes and fringe the streams of the district, oaks predominating, with numerous cedars on the higher summits (pls. 7, 8, 9). Two peaks, Mounts Scott and Sheridan, rise to an elevation of approximately 2,500 feet, at a distance of ro or 12 miles in a northerly direction from Cache, from which point, or from Fort Sill, they may be readily reached by team. A day was spent, from Cache as the point of departure, in a trip to Mount Sheridan.

As might be expected, owing to its low elevation and limited area, the locust fauna of the summit is essentially the same as that of the plains at its base, but scantier, the only variations found corresponding exactly with the difference in character of the habitats represented. On the bare rock slopes and weathered boulders of the summit of Mount Sheridan (pl. 9, fig. I) and of the outlying rocky spur near Mountain Park (p1. 7) were found relict colonies of Trimerotropis saxatilis (p. 40); in the woods about Mount Sheridan and along the stream at Cache are found the forest-loving species Spharagemon bolli, Melanoplus keeleri, robustus, and scudderi. Other species taken in the bunch-grass of the mountain-top were Mermiria bivittata and neomexicana, Syrbula admirabilis, Orphulella decora, Hippiscus rugosus, Melanoplus bispinosus and packardii, all species that are common on the plains. As a whole, insect life of all kinds was very scarce upon the summit.

Another capture of interest in this locality was that of a representative of Telmatettix, a genus distributed widely in Mexico and the far west, which was taken on the stony fragments in the stream-bed at the foot of the northern talus-slope of Mount Sheridan. 


\section{EXTENSION OF KNOWN RANGE.}

The data secured on this trip have greatly extended the known range of several species and two genera, as follows: Orphulella speciosa, south to Alabama. Trimerotropis saxatilis, west as far as Oklahoma. Dictyophorus reticulatus, north to northwest Georgia. Melanoplus fasciatus, south to Alabama and Arkansas. Melanoplus morsei, south to southern Mississippi. Melanoplus obovatipennis, south to southern Mississippi, in the nearly related form tepidus, which may intergrade. Paroxya hoosieri, south to southern Louisiana. Podisma (with a new species), south to Alabama. Telmatettix, northeast to Oklahoma.

\section{LIST OF NEW SPECIES AND VARIETIES SECURED.}

Nomotettix cristatus denticulatus.

Hippiscus immaculatus.

Podisma australis.

Melanoplus latens.
Melanoplus tuberculatus.

Melanoplus tribuloides.

Melanoplus tepidus.

Melanoplus scudderi latus.

\section{LOCALITIES AT WHICH COLLECTING WAS DONE.}

The following list includes the points at which collecting was done, however slight in amount, together with their approximate elevation and the date of visit:

Georgia :

Sand Mountain, near Trenton, Dade County, July 8, 9; I,500 feet. Alabama:

Trenton, Dade County, July ro; 730 feet.

Anniston, Calhoun County, July 12; 700 to 1,000 feet.

Cheaha Mountain, Talladega County, July 13; 2,000 to 2,400 feet.

Lookout Mountain, near Valley Head, DeKalb County, July II ; I,600 feet. McCalla Siding, Jefferson County, July I4; 450 feet.

Turnipseed's ranch, Talladega Co., near Cheaha Mt., July 13; 1,000 feet.

Tuscaloosa, Tuscaloosa County, July I5; 200 feet.

MississipPI :

Valley Head, DeKalb County, July II; I,025 feet.

Biloxi, Harrison County, July I9; I to 20 feet.

Gulfport, Harrison County, July I8, 21; I to 20 feet.

Hattiesburg, Perry County, July I7; r40 feet.

Meridian, Lauderdale County, July I6; 350 feet.

Loursiana :

Meridian, Lauderdale County, July $16 ; 350$
Nugent, Harrison County, July 20; 65 feet.

Buras, Plaquemines Parish, July 23; 5 feet.

Franklin, St. Mary Parish, July 24; ro feet.

Arkansas :

Milneburg, Orleans Parish, July 22; 5 feet.

Ashdown, Little River County, July 26 to 28 ; 330 feet..

Blue Mountain Station, Logan County, August 28; 540 feet.

Centerville, Yell County, August 3I; 450 feet.

Dardanelle, Yell County, August $3 \mathrm{I} ; 350$ to 500 feet.

DeQueen, Sevier County, July $29 ; 380$ feet.

Eagleton, Polk County, August $3 ;$ i,500 feet.

Fayetteville, Washington County, September 5; r,300 feet.

Magazine Mt., Logan Co., August 29; 1,800 to 2,800, chiefly at 2,600 feet.

Mena, Polk County, July 30,31 ; I, I50 to I,700 feet. 
Arkansas-Continued.

Ola, Yell County, August 30; 400 feet.

Rich Mountain, Polk County, August I, 2; 2,600 feet.

Rich Mountain Station, Polk County, August 3; 1,625 feet.

Van Buren, Crawford County, September I; 450 feet.

Winslow, Washington County, September 2 to 4 ; 1,700 to 2,100 feet.

INDIAN TERRITORY :

Caddo, Choctaw Nation, August 8; 700 feet.

Caddo Hill, Choctaw Nation, August 9; 800 feet.

Haileyville, Choctaw Nation, August 6; 650 feet.

Howe, Choctaw Nation, August 4, 5; 500 feet.

South McAlester, Choctaw Nation, August 7; 700 to 850 feet.

TEXAS:

ewoka, Seminole Nation, August 27;800 feet.

Wilburton, Choctaw Nation, August 27; 650 feet.

Amarillo, Potter County, August 19, 20; 3,600 feet.

Bonita, Montague County, August 14; 950 feet.

Clarendon, Donley County, August I8; 2,700 feet.

Denison, Grayson County, August II to $13 ; 700$ feet.

Myra, Cook County, August I4; 900 feet.

Quanah, Hardeman County, August 2I ; I,500 feet..

St. Jo, Montague County, August I4; I,I 40 feet.

OKLAHOMA:

Wichita Falls, Wichita County, August 15, 16; 950 feet.

Cache, Kiowa and Comanche Reservation, August 23, 25; I,275 feet.

Mountain Park, Kiowa and Comanche Reservation, August 22, 23; 1,360 to $\mathrm{I}, 690$ feet.

Mount Sheridan, base, Kiowa and Comanche Reservation, August 24; I,600 feet (est.).

Mount Sheridan, summit, Kiowa and Comanche Reservation, August 24; 2,500 feet.

Snyder, Kiowa and Comanche Reservation, August 23; I,350 feet.

Shawnee, Pottawottamie Nation, August 26; 1,000 feet.

\section{ANNOTATED LIST OF SPECIES.}

This list includes each species of adult Acridiidæ secured, the locality where taken, with brief notes on its abundance, habitat, and habits in the territory traversed. In some cases data on the early stages (in parentheses) are also included, but there are many, particularly among the species of Schistocerca and Melanoplus, which can not be identified with certainty. Dates and elevations will be found, if desired, in the preceding list of localities.

As has been stated, the entire territory lies in the Austral zones, and data are as yet insufficient for the preparation of satisfactory lists of species characteristic of each section of these zones. Consequently, in this list relatively few statements will be found regarding zonal distribution except in connection with the Transition or boreal faunal elements.

For several reasons it has seemed wisest to use, in the main, the same terminology as in my first report (Pub. No. I8), but Trachyrhachis has been substituted for Mestobregma. 


\section{TET'TIGINAE.}

Nomotettix cristatus scudder.

Georgia: Sand Mountain (juv.).

Alabama: Lookout Mountain (juv.).

Arkansas: Dardanelle (Mena, juv.).

Nomotettix cristatus denticulatus Morse.

Nomotettix crestalus denticulatus. Psyche, XI11, 119, 1906.

Indian Territory: Caddo (juv.); Haileyville; South McAlester (juv.).

Texas: Denison.

The variety denticulatus is distinguished by being more scabrous than the type form, with the margins of the pronotum very minutely serrulate, the sides of the vertex of the head less regularly convex, its carina less protuberant, the carina of the pronotum thinner and higher, the middle femora with undulate margins, and the upper edges of the hind femora with inwardly or upwardly directed denticulate projections. These characters are exhibited by a male from Denison, and the specimens from Indian Territory show them in lesser degree. All of the examples secured have a more elevated and thinner carina than New England specimens, approaching the compressus form.

This species is not uncommon locally on damp, sandy loam, thinly grassed or more or less exposed to light and sun, such as upland pastures at the North or the edges and openings of woods at the South. In summer the young are numerous, the adults very scarce.

Neotettix femoratus Scudder.

Georgia: Sand Mountain.

Alabama: Anniston; Lookout Mountain; McCalla; Tuscaloosa.

Mississippi: Biloxi; Gulfport; Hattiesburg; Nugent.

Arkansas: Ashdown; Dardanelle; DeQueen; Eagleton; Fayetteville; Mena;

Ola; Rich Mountain; Rich Mountain Station.

Indian Territory: Caddo; Haileyville; Howe; South McAlester; Wilburton.

One of the most plentiful species of Tettiginæ in the southeastern quarter of the country, often occurring in great abundance in specially favorable localities. Such a spot is shown in the frontispiece in the flat piney-woods of southwestern Arkansas. It is widely and rather generally distributed, preferring sandy soils which are frequently or perpetually moist. Both long-winged and short-winged forms were obtained, the latter being somewhat more plentiful.

\section{Tettix arenosus Burmeister.}

Georgia: Sand Mountain.

Alabama: Tuscaloosa; Valley Head.

Mississippi: Hattiesburg; Meridian.

Arkansas: Ashdown; DeQueen; Fayetteville; Ola; Winslow.

Indian Territory: Howe; South McAlester.

Texas: Denison. 
This, the most plentiful member of the genus in Austral regions, was taken at a number of localities in small numbers, usually on sandy loam, commonly in company with other members of the group, either Tettix, Neotettix, or Tettigidea.

\section{Tettix hancocki Morse.}

Arkansas: Fayetteville (juv.) ; Rich Mountain; Winslow.

Widely distributed in the Upper Austral and Transition zones of the central part of the country, generally occurring on moist upland soils of sandy texture, especially on high elevations.

\section{Tettix ornatus Say.}

Alabama: Valley Head.

Common in a valley pasture of three or four years' standing, and probably not eradicated from it during cultivation (see Paratettix cucullatus). This and the preceding species are of much more frequent occurrence in the Northern than in the Southern States, their range extending even into the Canadian zone. In the North this species is often associated with Nomotettix cristatus.

\section{Paratettix cucullatus Burmeister.}

Paratettix cucullatus abortus Hancock.

Alabama: Tuscaloosa.

Mississippi: Gulfport.

Arkansas: Ashdown; Blue Mountain Station; Dardanelle; DeQueen; Fayetteville; Magazine Mountain; Mena; Ola; Rich Mountain Station.

Indian Territory: Haileyville; Howe; South McAlester; Wewoka.

Texas: Bonita; Clarendon; Denison; Wichita Falls.

Oklahoma: Cache; Mountain Park; Shawnee; base of Mount Sheridan.

A very widely distributed and frequently very plentiful species frequenting the shores of ponds and streams, sloughs, springy runs, etc., from southern New England to Texas and Colorado. (See frontispiece.) At Dardanelle, Arkansas, it was exceedingly abundant in a moist, shallow gully in a cornfield on the sandy bottom-land along the Arkansas River.

Three specimens of the short-winged form abortus Hancock were secured at Gulfport, Mississippi, at a spring on the edge of the seabeach.

\section{Telmatettix aztecus Saussure.}

Oklahoma: base of Mt. Sheridan, Wichita Mountains.

A single male of this species was taken in the stony bed of a small stream at the foot of the northern talus slope of Mount Sheridan (p1. 8, fig. 2) hidden in the woods. 
Tettigidea armata Morse.

Arkansas: Ola.

Indian Territory: Howe.

One male and one female were taken with $T$. lateralis while sweeping in moist bottom-lands.

Tettigidea lateralis Say.

Georgia: Sand Mountain (juv.).

Alabama: Anniston; Lookout Mountain; McCalla; Tuscaloosa; Valley Head.

Mississippi: Gulfport; Hattiesburg.

Louisiana: Milneburg.

Arkansas: Ashdown; Dardanelle; DeQueen; Eagleton; Fayetteville; Magazine Mountain; Mena; Ola; Rich Mountain; Rich Mountain Station; Winslow.

Indian Territory: Caddo; Haileyville; Howe; South McAlester; Wewoka; Wilburton.

Texas: Bonita; Denison.

Tettigidea lateralis polymorpha Burmeister.

Arkansas: Ashdown; DeQueen; Mena; Ola.

Indian Territory: Howe; South McAlester.

This species, with Paratettix cucullatus and Neotettix femoratus, is one of the dominant Tettiginæ of the Southern States, occurring in countless numbers in wet bottomlands, along streams, and even at considerable elevations about springs, as on Magazine Mountain, Arkansas. The short-winged examples, usually referred to var. polymorpha, were much less plentiful than long-winged, and the males seem to greatly outnumber the other sex ; this, however, is very likely due to the greater sluggishness of the latter, rendering them less liable to capture in the sweeping-net.

The frontispiece shows a station where this species was extremely abundant.

\section{TRYXALINAE.}

\section{Tryxalis brevicornis Linné.}

Alabama: Tuscaloosa.

Louisiana: Franklin, Milneburg (juv. 4, 5).

Locally common in wet meadows, swamps, and along streams. At Tuscaloosa it was plentiful among peppermint in a springy area.

Mermiria alacris Scudder.

(Mermiria vigilans Scudder appears to be a synonym of this species).

Indian Territory: Wilburton (juv. 5).

Oklahoma: Shawnee.

Only half a dozen examples of this species were secured. These include male, female, and immature specimens and were taken among coarse grasses in the vicinity of a stream, and in a prairie meadow. 
Mermiria bivittata Serville.

Alabama: Cheaha Mountain.

Mississippi: (Biloxi, juv. 3, 4); (Hattiesburg, juv. 4); Nugent (juv. 3, $4,5)$.

Indian Territory: Caddo; South McAlester; Wilburton.

Texas: Amarillo; Bonita; Clarendon; Denison; Quanah; St. Jo; Wichita Falls.

Oklahoma: Cache; Mountain Park; base of Mount Sheridan.

This is a common, widely distributed, and rather variable species, which inhabits patches of bunch-grass (Andropogon, Chrysopogon, etc.), occurring in either wet or dry situations, but is usually more abundant in the latter (pl. 3, fig. I). The pale submarginal stripe on the tegmina varies from bright apple-green through greenish white to clear white, and is frequently lacking entirely in the male and either scarcely discernible or very distinct in the female. Unstriped specimens seem to be as widely distributed as striped ones.

\section{Mermiria neo-mexicana Thomas.}

Indian Territory: Caddo (juv. 2, 3).

Texas: Amarillo; Clarendon (juv. 5); Wichita Falls.

Oklahoma: Cache; Mountain Park; base and summit of Mount Sheridan.

This species is characteristic of the coarse grasses of the drier parts of the prairie-plains and is often locally abundant. Its habitat is well shown in foreground of plate 8 , fig. 2 .

\section{Syrbula admirabilis Uhl.}

Georgia: Sand Mountain; Trenton.

Alabama: Cheaha Mountain; Lookout Mountain; Tuscaloosa.

Mississippi: Biloxi; Nugent.

Louisiana: Franklin.

Arkansas: Ashdown; Blue Mountain Station; Dardanelle; DeQueen; Fayetteville; Magazine Mountain; Mena; Rich Mountain; Rich Mountain Station; Van Buren; Winslow.

Indian Territory: Caddo; Haileyville; Howe; South McAlester; Wilburton. Texas: Amarillo; Bonita; Clarendon; Denison; Myra; Quanah; St. Jo; Wichita Falls.

Oklahoma: Cache; Mountain Park; Shawnee; base and summit of Mount Sheridan.

This is one of the commonest and most generally distributed locusts in the South, occurring most abundantly among grasses in dry stations and waste places. During July immature examples greatly outnumbered adults, and various stages of the young were found throughout August, according to latitude and altitude. 
Eritettix carinatus Scudder.

Georgia: Sand Mountain.

Alabama: (Lookout Mountain, juv. 2); (Valley Head, juv. 2).

A single adult male and three nymphs in the second stage of development were the only specimens secured.

Eritettix sp.

Texas: (Clarendon, juv. 3 ).

A single specimen resembling the preceding species, but probably different.

\section{Eritettix sp.}

Texas: (Quanah, juv. 4).

One specimen, not identifiable specifically.

Amphitornus bicolor Thomas.

Texas: Amarillo; (Clarendon, juv. 3; (Quanah, juv. 4).

Oklahoma: Cache, Mountain Park.

One male and four females were taken, chiefly among mesquite grass, in company with Opeia obscura.

\section{Opeia obscura Thomas.}

Texas: Amarillo (juv. 5); Clarendon; Denison (juv. 5); Quanah; Wichita Falls (juv. 5).

Oklahoma: Cache; Mountain Park; base of Mount Sheridan.

In the drier parts of the prairie region and on the plains this species is common, even abundant locally, among the mesquite grass and other low herbage, particularly about the bare places surrounding the nests of the harvesting-ants. In color and form it so strongly resembles, the male especially, the scattered glumes of grasses and other débris of sweeping as to be overlooked readily by the collector, even when in the net.

Amblytropidia occidentalis Saussure.

Alabama: (Anniston).

Mississippi: (Biloxi; Gulfport; Meridian; Nugent).

Arkansas: (Blue Mountain Station; DeQueen; Eagleton; Mena).

Indian Territory: (Caddo; Haileyville; Howe; South McAlester).

Texas: (Bonita; Denison).

This locust is represented entirely by immature examples, ranging in development from the second stage, at Anniston, July I 2th, to the fifth stage at Blue Mountain Station on August 28th. It is widely distributed, and common locally. The adults frequent open forests and are plentiful in the autumn and winter. 
Cordillacris crenulata Bruner.

Texas: Amarillo.

Three females only of this species were found among the mesquite grass on the Staked Plains at Amarillo, in company with Opeia obscura and Phlibostroma quadrimaculatum.

\section{Phlibostroma quadrimaculatum Thomas.}

Texas: Amarillo; Clarendon; Quanah; Wichita Falls.

Oklahoma: Cache; Mountain Park.

A Great Plains species, not uncommon locally in mesquite grass, associated with Opeia, Ageneotettix, Encoptolophus costalis, etc.

\section{Orphulella olivacea Morse.}

Mississippi: Biloxi.

Louisiana: Buras.

This is a salt-marsh locust of very wide distribution along the Atlantic seaboard from Connecticut to Darien, and occurs only in salt or brackịsh marshes. Sometimes local and extremely plentiful, at Buras it was generally distributed throughout the portion of the marshes examined. It is probably found throughout the entire saltmarsh district of southern Louisiana.

\section{Orphulella pelidna Burmeister.}

Georgia: Sand Mountain; Trenton.

Alabama: Anniston; Cheaha Mountain; Lookout Mountain; McCalla; Turnipseed's Ranch; Tuscaloosa.

Mississippi: Biloxi; Gulfport; Hattiesburg; Meridian; Nugent.

Arkansas: Ashdown; DeQueen; Eagleton; Magazine Mountain; Mena; Ola; Rich Mountain; Rich Mountain Station; Winslow.

Indian Territory: Caddo; Haileyville; Howe; South McAlester; Wilburton. Texas: Bonita.

One of the most plentiful small locusts of the humid southeastern quarter of the country, widely and quite generally distributed in fields of sandy loam.

\section{Orphulella picturata Scudder.}

Arkansas: Ashdown; Blue Mountain Station; (Centerville, juv. 4, 5) ; Dardanelle; Magazine Mountain; Van Buren; Winslow.

Indian Territory: Haileyville; Howe.

Texas: Clarendon; Denison; Myra; Quanah; Wichita Falls.

Oklahoma: Cache; Mountain Park; Shawnee; Snyder.

This dainty little locust is a common and wide-spread species, plentiful in dry, open fields and prairies, particularly where rather thinly grassed, about ant-nests, old stack sites, prairie-dog mounds, etc. Like pelidna and speciosa, it presents a great variety of coloring. 
Orphulella speciosa Scudder.

Alabama: Cheaha Mountain.

A series of 9 males and $\mathrm{I} 3$ females was secured among the xerophytic vegetation of the summit of Cheaha Mountain. This is the most southern point from which the species is recorded in the East. The specimens taken vary from Northern examples in being larger and having longer wings.

\section{Orphulella decora McNeill.}

Arkansas: Magazine Mountain; Winslow.

Indian Territory: Haileyville; Howe; Wilburton.

Texas: Denison.

Oklahoma: Cache; Shawnee; summit of Mount Sheridan.

Though local, this species is not uncommon in the denser growths of grass in the damper parts of fields in the territory inhabited by it, while picturata prefers the shorter growths of drier soils. In structure there is a close parallelism between this species (or form) and the specimens of speciosa from Cheaha Mountain, when compared with Northern examples of speciosa.

\section{Dichromorpha viridis Scudder.}

Mississippi: Hattiesburg.

Arkansas: Ashdown; Blue Mountain Station; Dardanelle; DeQueen; Eagleton; Fayetteville; Magazine Mountain; Mena; Ola; Rich Mountain; Rich Mountain Station; Winslow.

Indian Territory: Howe.

Texas: Denison.

Oklahoma: Shawnee.

A widely distributed species of the humid part of the Austral zones, somewhat local in habitat, occurring usually among dense herbage in moist places, either fields, the edges of forests, the more open woodlands, or the vicinity of springs and streams.

\section{Clinocephalus elegans Morse.}

Mississippi: Biloxi (juv. 2, 3, 4, 5); Gulfport (juv. 5) ; Nugent (juv. 4, 5). Louisiana: Milneburg.

Common in the grass of swampy stations in woodland along the Gulf shore, and extending as far north as the vicinity of New York.

\section{Chloealtis conspersa Harris.}

Arkansas: Magazine Mountain, 2,60o feet.

A single male of this boreal species was secured in a rank growth of bunch-grass (Andropogon) in the border of a cultivated field surrounded by woodland, a station exactly like its preferred haunts in New England. This species deposits its eggs in decayed wood, hence its preference for the neighborhood of woodland, fence-rows, etc. 
Boöpedon auriventris McNeill.

Arkansas: Magazine Mountain; Mena.

Indian Territory: Caddo; Haileyville.

Texas: Denison.

This is an interesting sylvan species peculiar to the southern half of the forested region between the Mississippi River and the Great Plains. It was first met with at Mena, on the eastern slope of the foothills of Rich Mountain, in an open forest of pine and deciduous trees (pl. 3, fig. 2); at Haileyville and Caddo Hill in similar rocky, deciduous woodlands. At Magazine Mountain it was one of the notable assemblage of species which had gathered in the shrubby growth at the edge of the summit cliff (p1. 4, fig. 2). It is of sluggish disposition, and but few are seen, but when aroused it leaps powerfully, often two or three times in succession. In all, eleven males and ten females were captured. The males appear ridiculously small beside their huge mates.

\section{Boöpedon nubilum Say.}

Texas: Wichita Falls.

Two specimens were captured among the herbage at the roadside shown in plate 5 , fig. I.

\section{Ageneotettix deorum Scudder.}

Indian Territory: Caddo.

Texas: Amarillo; Bonita; Clarendon; Denison; Quanah; St. Jo; Wichita Falls.

This is a widely distributed species, locally common, especially on sandy soil with a sparse clothing of herbage, but also occurring frequently among the grass of arid localities. At Caddo Hill it was found on a sandy area of limited extent in the midst of an open woodland, this relation probably being due to the encroachment of the forests on earlier unforested territory.

The specimens taken are of large size, with relatively long tegmina and obtuse-angled vertex.

\section{Aulocara femoratum Scudder.}

\section{Texas: Quanah.}

Half a dozen examples of this species were secured among the grass in the vicinity of the stony hill-top shown in plate 6, fig. I.

Aulocara elliotti Thomas.

Oklahoma: Cache; Snyder.

Campestrian, among the mesquite grass of the fields. Two examples only. 


\section{OEDIPODINAE.}

Arphia xanthoptera Germar.

Alabama: (Anniston, juv. 4); (Lookout Mountain, juv. 3, 4); (McCalla, juv. 5).

Mississippi: Biloxi; (Meridian, juv. 5); Nugent (juv. 4).

Arkansas: (Ashdown, juv. 5); Blue Mountain Station; Dardanelle; (DeQueen, juv. 5); (Eagleton, juv. 4); Fayetteville (juv. 5); Magazine Mountain (juv. 5); (Mena, juv. 4, 5); Ola; (Rich Mountain, juv. 3, 5); Winslow.

Indian Territory: (Caddo, juv. 5); Haileyville; Howe (juv. 5); Wilburton. Texas: Clarendon; Denison.

Oklahoma: Cache; Shawnee.

This is a common species in dry fields and openings in woodlands throughout a large part of the eastern half of the country, maturing in the autumn.

\section{Arphia sulphurea Fabricius.}

Georgia: Sand Mountain.

Alabama: Cheaha Mountain; Lookout Mountain.

Mississippi: Meridian.

Arkansas: Mena; Rich Mountain.

Indian Territory: Caddo; Haileyville; Howe; South McAlester.

Found in the same stations as xanthoptera, but maturing in spring; no young were observed.

Arphia luteola Scudder.

Indian Territory: Caddo; Howe.

Texas: Denison; Wichita Falls.

A half-dozen specimens, all adult and some of them much worn, were captured among the weeds of old fields. The color of the wings varies from a lemon-yellow to a dull orange-buff, darkest in the oldest specimens.

Arphia simplex Scudder.

Indian Territory: Caddo Hill.

Three males with bright orange wings, from old fields.

Arphia nietana Saussure.

Texas: Quanah.

Two males only, from grassy fields.

\section{Chortophaga viridifasciata DeGeer.}

Georgia: Sand Mountain (juv. I, 2, 3, 4, 5); Trenton (juv. 3, 5).

Alabama: Anniston (juv. 2, 3, 4, 5); Lookout Mountain (juv. 4, 5); McCalla (juv. 5) ; Tuscaloosa (juv. 5); Valley Head (juv. 3, 4, 5).

Mississippi: Biloxi; Gulfport; Hattiesburg (juv. 5) ; Nugent.

Louisiana: Buras; Franklin; Milneburg (juv. 5). 
Arkansas: Ashdown (juv. 3, 4, 5); Blue Mountain Station (juv. 3, 4); Dardanelle (juv. 4) ; DeQueen (juv. 5) ; Eagleton (juv. 5); Fayetteville (juv. 3) ; Magazine Mountain; Mena (juv. 5) ; Ola; Rich Mountain; Rich Mountain Station; Winslow.

Indian Territory: Caddo; Haileyville; Howe (juv. 5); South McAlester; Wilburton (juv. 5).

Texas: Bonita; (Denison, juv. 3); Wichita Falls.

Oklahoma: Cache; Mountain Park (juv. 3); Shawnee (juv. 5).

This species is one of the most ubiquitous locusts of the eastern half of the continent, inhabiting a great variety of environments, chiefly campestral and on soil containing a moderate amount of moisture. It is one of the few species which has apparently extended its range down the Mississippi River along the levees, being common on the higher ground near the river and on embankments along canals.

\section{Encoptolophus parvus Scudder.}

Indian Territory: Caddo.

Texas: Amarillo; Clarendon; Denison; Quanah; Wichita Falls.

Oklahoma: Snyder.

A locally common species frequenting the dark, chocolate-colored humus of the exposed shores of dried-up ponds and ditches, and not infrequently found on cultivated fields. It is so inconspicuously colored and so nearly silent in flight as readily to escape notice either when on the wing or when at rest.

\section{Encoptolophus costalis Scudder.}

Texas: Amarillo; Clarendon; Myra; Quanah.

Locally common among the mesquite grass, varying much in coloration, specimens being occasionally light yellowish green, the markings contrasting strongly with the ground color. The green form bears a strong resemblance to Phlibostroma quadrimaculatum.

Hippiscus corallipes Haldeman.

Texas: Clarendon; Quanah.

Oklahoma: Cache; Mountain Park; Snyder.

A large, handsome, and wary species, not uncommon locally among mesquite grass and along roadsides.

Hippiscus immaculatus Morse.

Hippiscus immaculatus. Psyche, XIII, I19, 1906.

Texas: Clarendon. One male.

"The specimen [described] is the size of rugosus. The pronotum is less rugose, smoother in outline and in surface, a little narrower; the hind margin is obtuse-angulate, its apex rounded and its sides 
straight. Wings like those of rugosus, the tip infuscated but not maculate. Ground-color of tegmina a pale, almost vinaceous brown; the basal half of the anal field suffused with fuscous except along the anal vein; the distal half of the costal field more or less suffused and the basal third finely maculate, the proximal part of the discoidal field evenly suffused, the veins and venules of the distal part more or less infuscated apically, and a slight fuscous suffusion near the base.

"Compared with rugosus the specimen differs relatively little structurally or in wing-marking, but radically in the tegminal pattern, which suggests that of tuberculatus, but is much less distinct."

Hippiscus phoenicopterus Germar.

Georgia: Sand Mountain; Trenton.

Alabama: Cheaha Mountain; Lookout Mountain; Turnipseed's Ranch.

Mississippi: Meridian; Nugent.

Arkansas: Magazine Mountain; Rich Mountain.

Indian Territory: Caddo; Haileyville; Howe.

In early summer this is the commonest species of the genus from Arkansas eastward. It frequents fields and waste grounds, sometimes entering the more open forests.

\section{Hippiscus rugosus Scudder.}

Georgia: (Trenton, juv. 4).

Alabama: Anniston (juv. 4, 5); (Lookout Mountain, juv. 3) ; McCalla, juv. 3, 5).

Mississippi: Biloxi (juv. 2); Gulfport; Hattiesburg (juv. 2); Meridian (juv. 2) ; Nugent (juv. 4, 5) ; (Tuscaloosa, juv. 2, 3, 4, 5).

Arkansas: (Ashdown, juv. 5); Blue Mountain Station; Dardanelle (juv. 5) ; Fayetteville (juv. 5); Magazine Mountain (juv. 4); (Rich Mountain, juv. 3); (Rich Mountain Station, juv. 3); Van Buren, Winslow (juv. 5).

Indian Territory: Caddo (juv. 5); Haileyville (juv. 5); Howe (juv. 3, 4, 5); South McAlester (juv. 5); Wilburton.

Texas: Amarillo; Bonita; Clarendon; Denison; Quanah; Wichita Falls.

Oklahoma: Cache; Mountain Park; Shawnee; base and summit of Mount Sheridan.

A very common and widely distributed species, often abundant locally.

Hippiscus saussurei Scudder.

Texas: Amarillo; Bonita; Wichita Falls.

Two males and two females from open weedy fields. A very large, active, and exceedingly wary locust. 
Leprus wheeleri Thomas.

Texas: Clarendon; Quanah (juv. 3, 4, 5); Wichita Falls.

Four adults and several young were taken on roadsides and in open fields, the young on the stony rise shown in plate 9 , fig. I. These were of a very pale bluish-gray, the color of the soil on which they lived.

\section{Tropidolophus formosus Say.}

Texas: Amarillo.

Two specimens were secured among the Euphorbia and other coarse weeds on an old road-plowing (p1. 9, fig. 2).

\section{Dissosteira carolina Linné.}

Georgia: Sand Mountain; Trenton.

Alabama: Anniston; Cheaha Mountain; Lookout Mountain; (McCalla, juv. 4); Valley Head.

Mississippi: (Hattiesburg, juv. 4); Meridian.

Arkansas: Blue Mountain Station; Dardanelle; Fayetteville; Magazine Mountàin; Mena; Ola; Rich Mountain; Rich Mountain Station; Winslow.

Indian Territory: Caddo; Haileyville; Howe; South McAlester.

Texas: Amarillo; Clarendon; Denison.

Oklahoma: Cache; Mountain Park; Shawnee; Snyder.

This very common and widely distributed species was met with at practically every locality visited, inhabiting roadsides, waste places, and all spots of bare ground, in city or country alike.

\section{Dissosteira longipennis Thomas.}

Texas: Amarillo; Clarendon; Wichita Falls.

Oklahoma: Mountain Park.

Very common on the arid plains, associating with Trimerotropis latifasciata, Spharagemon aequale, and its relative carolina on roadsides and other exposed soil surfaces. It is distinctly warier and takes longer flights, consequently is more difficult to capture, than carolina.

\section{Spharagemon aequale Say.}

Texas: Amarillo; Clarendon; Quanah; Wichita Falls.

Oklahoma: Cache; Mountain Park; base of Mount Sheridan.

This large and strikingly handsome species is very common on bare soil on the arid plains, whirring up from the roadside in numbers in company with species of Trimerotropis, Hadrotettix, and Dissosteira. Active and wary, however, either strategy or plentiful exercise is necessary to secure it in series. Examples are frequently met with having the metazona white, presenting a conspicuous collared pattern of marking. 
Spharagemon bolli Scudder.

Georgia: Sand Mountain.

Alabama: Cheaha Mountain; Lookout Mountain; Turnipseed's Ranch.

Mississippi: Meridian.

Arkansas: Ashdown; Blue Mountain Station; DeQueen; Eagleton; Fayetteville; Magazine Mountain; Mena; Ola; Rich Mountain; Rich Mountain Station; Winslow.

Indian Territory: Caddo; Haileyville; Howe.

Texas: Bonita; Denison.

Oklahoma: Mount Sheridan, at base and near summit, among woods.

This species is one of the few sylvan geophilous locusts, its distribution coinciding with that of dry woodlands, in which it is usually associated, in the region under discussion, with Melanoplus keeleri and robustus or their varieties. In the Northern States it frequents sandy old fields as well as the more open woods and forest paths and margins. It is very widely and generally distributed in suitable localities throughout its range, never becoming abundant, even locally.

\section{Spharagemon cristatum Scudder.}

Texas: Bonita; Clarendon; Quanah; Wichita Falls.

Oklahoma: Cache; Mountain Park; Shawnee.

This is a characteristic ammophilous species whose distribution seems to be controlled by, or at least coincident with, the presence of areas of loose sand or very light soil. In favorable spots it is plentiful and easily secured.

Scirtetica picta Scudder.

Mississippi: Gulfport.

Common along the upper part of the sea-beach and on open sandy spots not far inland. In the specimens secured the dusky wing-bands are narrower than in typical picta.

\section{TRACHYRHACHIS (MESTOBREGMA).}

Reference has been made in the introductory pages to the variation presented by the material secured in this genus, representing four or more so-called species varying in wing-coloration geographically and presenting a complete gradation from a wing with hyaline base and vitreous apex to one with bright lemon-yellow disk, crossed by a broad fuscous band.

Trachyrhachis thomasi Caudell.

Arkansas: Fayetteville; Van Buren.

Indian Territory: Caddo; Haileyville; Howe.

Texas: Denison; Quanah; Wichita Falls.

Oklahoma: Base of Mt. Sheridan. 
Trachyrhachis fuscifrons Stål.

Texas: Clarendon; Denison; Quanah; Wichita Falls.

Oklahoma: Cache; Mountain Park; Shawnee.

\section{Trachyrhachis obliterata Bruner (?).}

Texas: Amarillo; Clarendon; Denison; Quanah; Wichita Falls.

Oklahoma: Cache; Mountain Park.

Trachyrhachis kiowa Thomas.

Texas: Amarillo.

Oklahoma: Mountain Park.

The following statements, together with those on page 12, will bring out the geographical character of the variation presented.

Amarillo: 39 specimens. 38 kiowa, I obliterata.

Clarendon: 5 specimens. 2 obliterata; 3 fuscifrons, I with very narrow wing-band.

Quanah: 44 specimens. 20 thomasi; 15 fuscifrons grading perfectly into thomasi; 7 obliterata, grading toward fuscifrons in showing traces of wing-band; 2 with disk hyaline and wing-band obsolescent or of medium width.

Wichita Falls : 23 specimens. 4 obliterata; I with disk hyaline and wing-band broad, nearly complete; 16 fuscifrons grading toward thomasi, chiefly with wing-band broad in posterior part, but broken behind radial shoot, which is often faint.

Mountain Park: 6 specimens. 2 kiowa; 3 obliterata; I fuscifrons with very faint wing-band.

Shawnee : I specimen. Like last.

Cache: 3 specimens. 2 obliterata; I fuscifrons with pallid disk.

Base of Mt. Sheridan : I thomasi, varying toward fuscifrons.

Caddo, I; Haileyville, 19; Howe, 25; Van Buren, 9; Fayetteville, 3o, all thomasi.

Specimens of Trachyrhachis are very common and generally distributed on drier grounds of prairies and plains, especially in the vicinity of bare spots, ant-fields, etc., among the mesquite and other low grasses.

Metator pardalinus Saussure.

Texas: Amarillo.

One male.

Psinidia fenestralis Serville.

Mississippi: Biloxi; Gulfport; Hattiesburg; Nugent.

Texas: Bonita; Clarendon.

An ammophilous species, widely distributed but very local, found only upon areas of loose sand. 
Trimerotropis bruneri McNeill.

Texas: Clarendon.

One male, referred to this species with some doubt.

Trimerotropis citrina Scudder.

Georgia: Trenton.

Alabama: Anniston, Turnipseed's Ranch; Tuscaloosa.

Mississippi: Gulfport (juv. 5) ; Hattiesburg; Meridian; Nugent.

Louisiana: Milneburg.

Arkansas: Ashdown; Blue Mountain Station; Dardanelle; Eagleton; Mena;

Rich Mountain Station; Van Buren; Winslow.

Indian Territory: Haileyville; Howe.

Texas: Amarillo; Bonita; Clarendon; Wichita Falls.

Oklahoma: Cache; Mountain Park; Shawnee; Snyder.

This is a very widely distributed species, of common occurrence throughout the Southern States from the seashore to a considerable elevation, frequenting, in company with Dissosteira carolina, roadsides and other spots bare of vegetation. Its coloring varies greatly according to the tint of the soil of its background, from dull white, through shades of yellowish and reddish brown, to a dull gray.

\section{Trimerotropis latifasciata Scudder.}

Texas: Amarillo; Clarendon; Quanah; Wichita Falls.

Oklahoma: Cache; Mountain Park.

This seldom-recorded species proves to be plentiful in northwestern Texas and Oklahoma, where it is found in abundance, associated with Spharagemon aequale, etc., on roadsides and bare spots, flying up in numbers before the feet of the traveler. It is a conspicuous insect in flight, with its broad, black wing-band, but is not so shy, nor is its flight so prolonged, as that of aequale, which it greatly outnumbers.

Trimerotropis modesta Bruner.

Texas: Clarendon.

One male, referred to this species with considerable doubt.

Trimerotropis saxatilis McNeill.

Georgia: Sand Mountain.

Arkansas: Dardanelle; Magazine Mountain; Winslow.

Indian Territory: Haileyville.

Oklahoma: Mountain Park; summit of Mount Sheridan.

This is one of the most interesting locusts met with on the trip. Though a near relative of vinculata, which is an inhabitant of roadsides and waste places, so closely allied to it as to be confused therewith except by one thoroughly acquainted with both species and their habits, this species is apparently purely saxicolous. Recorded from southern Illinois and northwestern Arkansas by McNeill, in I903 I found it on Stone Mountain, north central Georgia, and Sand Moun- 
tain, in the extreme northwestern corner of that State. The past season I traced it westward into Indian Territory and Oklahoma, finding it in similar rocky habitats. Specimens from Georgia and Oklahoma differ so greatly in size, prominence of eyes, and other minor characters that they would be separated as distinct species but for the intergrades from Indian Territory and Arkansas. Oklahoma examples are especially liable to be mistaken for vinculata, but the two species can readily be distinguished in habitus, habitat, and habits.

Saxatilis has been taken only on rock-surfaces, sometimes lichencrusted, sometimes bare and sun-scorched, either wholly unprotected from sun and storm or amid a considerable growth of forest which has sprung up since the station was colonized by the locust. Georgia habitats are shown in my first report (Publication No. I8, Carnegie Institution of Washington, p1. 2, figs. I, 2). In Arkansas it was common on Dardanelle Rock, on the rim rock at the edge of the summit cliff of Magazine Mountain (pl. 4, fig. I), and at Wheeler's Fall at Winslow. At Haileyville, Indian Territory, a few specimens were secured on the summit outcrops of rocky ridges covered with deciduous trees. In Oklahoma it was taken at Mountain Park on the rock slopes of an outlying spur of the Wichita Mountains (pl. 7, fig. 2) and on the ledges and boulders on the summit of Mount Sheridan (pl. 9, fig. I).

In color and markings it so closely resembles the background of its habitat as to be indistinguishable therefrom when at rest. Five specimens are shown in plate $I$, fig. 2 , and all would be practically invisible but for the shadows cast by the late afternoon sun at the time the photograph was taken. The ground coloration varies enormously, in correspondence with the background, from deep fuscous, ranging through various shades of brown and gray to nearly white. In the Wichita Mountains it matches the flesh-color of the weathered granite. The fuscous markings are usually strong, contrasting greatly with the ground-color if that is pale, but aiding in concealment on the mottled background.

It is a sluggish, unsuspicious species, flying but a short distance when disturbed, often with a distinct but relatively faint crepitation, and is easily captured. In the past season specimens were first met on Sand Mountain, Georgia, July 8. At this time adults of both sexes were numerous, the males actively searching for and attentive to the females, excitedly approaching them and fiddling with rapid vertical movements of the closed hind legs, ranging in extent from $5^{\circ}$ to $50^{\circ}$ (sometimes even $90^{\circ}$ ). Usually no sound was audible (to me) during this act of stridulation, but occasionally I could catch a distinct and rather pleasant "seep," resembling a bird-note at a distance rather 
than the note of an insect. The female made similar motions, but less often and less energetically.

When driven upon a background at variance in color with their own, no uneasiness was exhibited, but after a time they crawled away. Active in direct sunshine, they became sluggish when clouds obscured the sun, and at this time were very easy to approach, allowing the hand to come within 2 or 3 inches if it were advanced with caution.

\section{Trimerotropis vinculata Scudder.}

Texas: Amarillo; Clarendon; Wichita Falls.

A common species on the arid plains and westward. It is much less conspicuous in flight than its associates, Spharagemon aequale, Trimerotropis latifasciata, and Hadrotettix trifasciatus, owing to its narrower wing-band, less deeply colored disks, and smaller size.

\section{Hadrotettix trifasciatus Say.}

Indian Territory: Caddo Hill; South McAlester.

Texas: Quanah; Wichita Falls.

Oklahoma: Mountain Park; base of Mount Sheridan.

This handsome locust is one of the largest and most striking species of the section of country examined. Owing to its wariness and powerful flight it is a difficult insect to capture in numbers, though it is not uncommon locally on bare or thinly grassed soil, along roads, about washes and excavations, and in stony ground. At Caddo Hill one of its stations was in an open woodland, but it is typically a creature of the treeless plains (pl. 5, fig. I; pl. 6, fig. I).

\section{Brachystola magna Girard.}

Texas: Amarillo; Quanah.

\section{Oklahoma: Cache.}

A huge and sluggish species, not uncommon locally on sunflowers and other tall weeds, clambering clumsily about or resting quietly when undisturbed. Specimens kept alive over night were observed to stridulate, apparently by elevating the tegmina and beating the wings against them. (Cf. Dictyophorus reticulatus.) Both sexes did this, but the sound produced by the female was much the fainter.

Though commonly ranked as a geophilous desert species, in habits and in the structure of the tarsi this is a purely phytophilous locust. The form of the vertex of the head; the variable, but often distinct and sometimes conspicuous prosternal spine; the presence of the terminal spine of the outer row of the hind tibir; the form of the hind femora, and of the subgenital plate of the male; the texture of the surface of the body ; as well as the highly developed pulvilli and phytophilous habit of life-all seem to indicate the possibility of a closer kinship with the Acridiinæ than with the Oedipodinæ. 


\section{ACRIDINAE.}

Dictyophorus reticulatus Thunberg.

Georgia: (Trenton, juv. 4, 5).

Alabama: (Turnipseed's Ranch, near Cheaha Mountain, juv. 5).

Mississippi: Hattiesburg.

Louisiana: Milneburg.

These elephantine locusts, locally known as "devil-horses," were found in numbers resting upon the tall, coarse weeds at the side of the road through the swamp at Milneburg; at Hattiesburg a single adult was found in bottomland forest; and several immature specimens were taken among weeds in a mowing-lot at Trenton, Georgia, at an elevation of 730 feet, much farther northward than had been expected.

When disturbed the tegmina are often elevated and the brilliant carmine wings rapidly vibrated, producing a buzzing noise. If taken in hand, a disagreeable, dark-brown, frothy liquid is effused with a hissing sound from the mesothoracic spiracles, which probably is repugnatory in function.

\section{Leptysma marginicollis Serville.}

Mississippi: Biloxi; Gulfport; (Nugent, juv. 2, 3, 4).

Louisiana: (Buras, juv. 4, 5); Milneburg.

Texas: (Wichita Falls, juv. I, 2, 3, 5).

Common locally in the rush and sedge plant-societies of the margins of streams and ponds.

Schistocerca albolineata Thomas.

Texas: Wichita Falls.

A single pair among tall grass and shrubbery on the bank of a slough.

Schistocerca alutacea Harris.

Alabama: Cheaha Mountain.

Mississippi: Gulfport.

Arkansas: Eagleton; Fayetteville; Mena; Rich Mountain Station.

Of this species or form a few scattering examples were taken (see remarks under mbiginosa).

Schistocerca rubiginosa Harris-Scudder.

Mississippi: Nugent.

Arkansas: Magazine Mountain.

Indian Territory: Caddo.

Texas: Bonita.

Oklahoma: Shawnee. 
A dozen examples of this form were taken. Neither this nor the preceding were secured in sufficient series to enable satisfactory conclusions regarding the relation of the two forms in the territory under examination to be formulated (see remarks following S. obscura).

Schistocerca americana Drury.

Georgia: Trenton.

Alabama: Valley Head.

Mississippi: Gulfport; Nugent.

Louisiana: Franklin.

Arkansas: Dardanelle; Fayetteville; Rich Mountain; Van Buren; Winslow.

Indian Territory: Caddo; Wilburton.

Texas: Denison; Wichita Falls.

Oklahoma: Cache; Shawnee.

The data given above refer to actual captures. This species is one of the most ubiquitous locusts of the Southern States, and was either seen or secured at practically every point visited. Although very plentiful in places, at no point was it met with in seriously destructive numbers.

Schistocerca lineata Scudder.

Indian Territory: Caddo.

Texas: Clarendon.

Oklahoma: Cache; base of Mount Sheridan.

Locally plentiful, varying much in color of hind tibiæ, which are sometimes infuscated throughout, on the basal two-thirds alone, or even luteous with only the spines black-tipped.

It is usually found among the sunflowers and other coarse weeds along gullies, roadsides, and fences.

Schistocerca obscura Fabricius.

Mississippi: Hattiesburg.

Louisiana: Franklin; Milneburg.

Arkansas: Ashdown.

Indian Territory: Caddo.

Texas: Denison; Wichita Falls.

This is a robust, dark-colored species, which is common and widely distributed through the Southern States, usually occurring in coarse weeds and grasses in swamps and along streams.*

Much work remains to be done upon this genus in the way of careful collecting and observation, securing large series, before any-

*This species was accidentally included under the head of alutacea in my first report (Publication No. 18, Carnegie Institution of Washington). All of the specimens there reported from Savannah and Tybee Island, and a part of those from Carrabelle, belong to this species. 
thing definite will be known regarding the relations of the different forms to which the rank of species is usually applied. It is very probable that some so-called species are but forms of one which varies greatly in color and structure. In New England the two forms known as alutace and rubiginosa seem to be constantly different structurally, though rubiginosa has a color-variety resembling alutacea. Southward and westward the structural gap between the two seems to be bridged, and both vary much in size, color, form, and proportion of parts. It is highly probable that other groups of species in this genus present an equal amount of variation.

Hypochlora alba Dodge.

Indian Territory: Caddo.

Texas: Wichita Falls.

Oklahoma: Cache; Shawnee; base of Mount Sheridan.

Locally common on white sage (Artemisia sp.), in color exactly matching the greenish-white tints of its background (pl. I, fig. r). It prefers to escape observation by remaining quiet, but can leap well on occasion.

Campylacantha olivacea Scudder.

Arkansas: Fayetteville; Van Buren.

Indian Territory: Haileyville; Howe; South McAlester; Wilburton.

Texas: Amarillo; Clarendon; Quanah; Wichita Falls.

Oklahoma: Cache; Mountain Park; Shawnee; base of Mount Sheridan.

This species, with its color-variety acutipennis, is a widely distributed and often locally very common locust, occurring among weeds in fields, along fence-rows, and woodland edges. The green form very greatly outnumbers the gray, though the latter is by no means uncommon. It matures late, young being common until September, and the adults even seem relatively soft-bodied and usually discolor to a dull brown in drying. It is very sluggish, relying upon its protective coloration, rather than activity, to escape destruction.

Hesperotettix brevipennis Thomas.

Georgia: Sand Mountain.

Alabama: Cheaha Mountain; Lookout Mountain; Turnipseed's Ranch.

This is the eastern representative, a near relative, and probably the direct descendant of $H$. pratensis. Three males and a female were captured. Of these a male from Sand Mountain presents an interesting structural variation in the doubling of the subapical tubercle of the subgenital plate through a bifurcation of its tip, a shallow sulcus, one-half as deep as wide, separating the two apices. 
Hesperotettix pratensis Scudder.

Arkansas: Magazine Mountain.

Indian Territory: Caddo; South McAlester; Wilburton.

Texas: Denison.

This species was quite common in the grass and shrubby sprouts of the habitat shown in plate 6, fig. 2, at the edge of the summit cliff of Magazine Mountain, and the specimens secured there are of particular interest in presenting a pattern of coloration and a degree of wingdevelopment intermediate between typical pratensis and brevipennis.

Hesperotettix speciosus Scudder.

Indian Territory: Caddo.

Texas: Clarendon; Myra; Quanah; Wichita Falls.

Oklahoma: Cache; Mountain Park.

Not uncommonly obtained while sweeping, but seldom occurring nn numbers. Decidedly less active than its long-winged relative viridis.

Hesperotettix viridis Thomas.

Texas: Quanah; Wichita Falls.

Very common in one station among weeds.

Aeoloplus regalis Scudder.

Texas: Wichita Falls.

Plentiful on a weedy patch about a stone-heap in cultivated ground in company with large numbers of Melanoplus differentialis, several other species of that genus, Hesperotettix, and two species of Decticinæ.

Podisma australis Morse.*

Podisma scudderi. Psyche, XII, 120, 1906.

Podisma australis. Psyche, XrV, 57, 1907.

Alabama: Cheaha Mountain. One female.

"Head large, eyes large and prominent, vertex very blunt, but little protuberant, in form and proportions recalling Dendrotettix. Pronotum robust, depressed rather than compressed, especially at the shoulders; carina distinct on metazone, evanescent on prozone; posterior margin slightly convex, subemarginate; sutures deeply impressed. Prosternal spine short, acutely pointed, conical with excavate sides. Tegmina ovate-lanceolate, separated by their own width, anterior margin strongly convex, posterior slightly so, apex evenly rounded. Carina of the abdomen indistinct. Valves of ovipositor stout, outer margins finely dentate and strongly sinuate, contrasting markedly in

*Owing to the fact that in a single instance, many years ago, Melanoplus scudderi had been referred to the genus Podisma (Walker, Cat. Derm. Salt. Brit. Mus., Iv. 718,1870 ), strict rules of nomenclature seemed to render a different name advisable for this species. 
robustness with the same organs in $P$. glacialis variegata, from which the presence of tegmina distinguishes it at a glance.

"Color luteous beneath; above mixed olive-green, fuscous, and brown with more or less purple or cherry-red on inner and outer faces of hind femora. Feet greenish; tibiæ mixed, strongly pubescent, with black spines.

"Length: 25; hind fem.: I2; pronotum: 5 ; tegmina: 4 by $2.5 \mathrm{~mm}$.

" This is a stout species, resembling Dendrotettix in the form of the head and proportions of the eyes, and the discovery of the male is awaited with interest. The single example secured was taken while sweeping grass and shrubbery in the vicinity of Pulpit Rock, near the summit of the mountain. Protracted search for a male or additional examples was unavailing."

\section{Paratylotropidia brunneri Scudder.}

Arkansas: Magazine Mountain; Mena.

Indian Territory: Caddo Hill.

Five examples of this rare species were captured among the shrubby undergrowth of dry, stony woodlands (p1. 3 , fig. 2), and at the station shown in plate 4 , fig. 2 .

\section{MELANOPLUS.}

For convenience of reference the species of this extensive genus are here arranged alphabetically.

\section{Melanoplus atlanis Riley.}

Georgia: Sand Mountain; Trenton.

Alabama: Anniston; Lookout Mountain; Valley Head.

Mississippi: Hattiesburg.

Louisiana: Franklin.

Arkansas: Blue Mountain Station; Dardanelle; Fayetteville; Magazine Mountain; Mena; Ola; Rich Mountain; Van Buren.

Indian Territory: Caddo; Caddo Hill; Howe.

Texas: Bonita; Denison; Myra; Quanah; Wichita Falls.

Oklahoma: Cache; Mountain Park; Shawnee.

This is a common species, often locally abundant, frequenting dry, grassy fields. While not met with in such numbers as to be seriously injurious, it was very plentiful on the abandoned farms on the summit of Rich Mountain.

\section{Melanoplus bispinosus Scudder.}

Arkansas: Ashdown; Van Buren.

Indian Territory: Caddo Hill; South McAlester; Wilburton.

Texas: Clarendon; Denison; Quanah; St. Jo; Wichita Falls.

Oklahoma: Cache; Shawnee; base and summit of Mount Sheridan.

A very common and widely distributed campestrian species. 


\section{Melanoplus bivittatus Say.}

Indian Territory: Caddo; Wilburton.

Texas: Denison.

Oklahoma: Cache; base of Mount Sheridan; Snyder.

Common locally in the herbage of moist meadows, about springs, along ditches and streams.

Melanoplus bivittatus femoratus Burmeister.

Georgia: Sand Mountain.

Alabama: Cheaha Mountain.

The specimens secured are markedly different in color from northern examples; the olivaceous tinge so common in northern specimens is entirely lacking; the general coloration is a brownish fuscous above, luteous beneath. The hind tibiæ are red, more or less-sometimes strongly-infuscated on the basal half; and the hind femora show the strong fuscous longitudinal stripe of the glaucous-legged form.

Melanoplus differentialis Uhler.

Louisiana: Franklin.

Arkansas: Fayetteville.

Indian Territory: Caddo; Howe.

Texas: Amarillo; Clarendon; Denison; Quanah; Wichita Falls.

Oklahoma: Cache; Mountain Park; Shawnee; base of Mount Sheridan.

Locally common, often abundant and destructive, among coarse grasses and weeds in waste places. Very widely but erratically distributed.

\section{Melanoplus discolor Scudder.}

Texas: Amarillo.

Three males and two females among tall grasses on the plains.

Melanoplus fasciatus Barnston-Walker.

Alabama: Cheaha Mountain.

A single male of this boreal species was captured among the xerophytic vegetation on the summit of this, the highest mountain in Alabama. In this specimen the fuscous fasciæ of the hind femora are nearly obsolete. This capture extends its range southward from New Jersey, where it is common in cranberry bogs. A comparison of one of McNeill's types of M. baconi in the Scudder collection demonstrates its identity with this species.

\section{Melanoplus femur-rubrum DeGeer.}

Arkansas: Dardanelle; Fayetteville; Magazine Mountain; Ola; Rich Mountain; Van Buren; Winslow.

Indian Territory: Haileyville; Howe; South McAlester; Wilburton.

Texas: Amarillo; Clarendon; Quanah.

Oklahoma: Shawnee. 
A widespread and locally plentiful campestrian species inhabiting by preference moist fields and meadows. At Amarillo red-legged examples were scarcely more numerous than those with pale glaucous or bluish hind tibiæ, and similar specimens were common at Fayetteville.

Melanoplus flavidus Scudder.

Texas: Clarendon.

A single pair. Campestrian.

Melanoplus foedus Scudder.

Arkansas: Dardanelle.

Texas: Wichita Falls.

Oklahoma: Shawnee.

This species was found among tall weeds and grasses along the banks of streams and flood channels, occurring plentifully in the localities named. Specimens vary much in color of hind legs, and apparently the species runs into packardi.

Melanoplus glaucipes Scudder.

Texas: Bonita.

Oklahoma: Mountain Park.

A sluggish species, living among bunch-grass in arid stations.

Melanoplus gracilis Bruner.

Arkansas: Magazine Mountain, 2,400 feet.

This species was detected but once, in a cool, damp thicket on the heavily shaded northern side of Magazine Mountain, almost within the shadow of the summit escarpment (see p. I8). Here it was not uncommon, but very alert and secretive, seldom showing itself, and quick to leap away. It should be sought in similar stations throughout the forested sections of Arkansas and the neighboring States.

Melanoplus impiger Scudder.

Texas: Bonita; Clarendon.

Oklahoma: Shawnee.

In the single male obtained at Shawnee the digits of the furcula are exceptionally long, very nearly one-half as long as the supra-anal plate, cylindrical save at base, and diverge in a gentle curve; in the other specimens secured they are noticeably flattened for half their length and less divergent. The color of the hind tibiæ varies from deep blue to cherry-red.

At Bonita this locust was common in the open forest of oaks and hickories, of which the Upper Cross Timbers is largely made up, and in the open fields as well. 
Melanoplus impudicus Scudder.

Georgia: Sand Mountain.

Alabama: Cheaha Mountain; Lookout Mountain.

Mississippi: Meridian.

Arkansas: Blue Mountain Station; Eagleton; Mena.

Indian Territory: Caddo; Howe.

A widely distributed but somewhat local species frequenting the grasses of dry, open woodlands and sometimes also in fields of sandy or stony soil.

Melanoplus keeleri Thomas.

Arkansas: Blue Mountain Station; Fayetteville; Magazine Mountain, 2,000 to 2,800 feet; Ola; Winslow.

Indian Territory: Caddo Hill; Haileyville; Howe; South McAlester; Wewoka; Wilburton.

Texas: Bonita; Denison.

Oklahoma: Cache; Mountain Park; base of Mount Sheridan.

As remarked by McNeill (Psyche, vIII, 366) it seems to be impossible to draw any satisfactory line between the forms known as keeleri, deletor, and luridus in reference to Arkansas material. Over I 30 examples of this species were secured, including several series of a dozen to twenty specimens from the same locality. These vary greatly in the form of the cerci among individuals from the same place. In general, it may be said that the more southern examples approach more nearly to the keeleri and deletor type, and the more northern to the luridus pattern. Elucidation of the distribution and relation of these forms will require careful and systematic collecting with direct reference to this particular problem.

This is a very common species in and near woodlands, apparently not occurring on the treeless plains.

Melanoplus lakinus Scudder.

Texas: Amarillo.

About a dozen short-winged examples were secured from tall grass and weeds.

\section{Melanoplus latens Morse.}

Melanoplus latens. Psyche, X111, 120, 1906.

Indian Territory: Caddo Hill.

Six males, seven females.

To this species I refer also three females from Bonita, Texas; Howe, Indian Territory; and Magazine Mountain, Arkansas.

"A short-winged, red-legged species having much the habitus of $M$. scudderi and occurring with it in thickets and woodlands. Tegmina acutely pointed, equaling head and pronotum. Vertex of head 
rather protuberant. Midcarina of pronotum distinct, equally developed throughout. Prozona slightly inflated. Hind tibiæ cherry-red.

"Subgenital plate of male from above rounded apically, in side view short, its lateral and ventral outlines nearly equal, a little elevated apically. Furcula obsolete or represented by two small, rounded protuberances. Last dorsal segment a little emarginate. Cerci long, a little surpassing the supra-anal plate, two and a half times or more as long as their basal breadth, nearly four times as long as their middle breadth, tapering rapidly on basal fourth, bent slightly upward at this point, subequal or slightly expanded subapically, tapering to a rounded, flattened apex. Valves of ovipositor of female short, rather blunt, and usually dull-pointed.

"Length : male, I9-22; female, 27-30. Hind femora: male, I2I3 ; female, I4.5-16. Tegmina : male, 6.5-7 ; female, 7-8.5 mm."

Melanoplus morsei Blatchley.

Mississippi: Hattiesburg.

A single pair of this species was taken in woodland on sandy, river bottom-land, in company with $M$. viola. These are so large that measurements are appended. Length: Male, 22; female, 28 . Hind femora: Male, I2; female, $24 \mathrm{~mm}$.

\section{Melanoplus obovatipennis Blatchley.}

Arkansas: Blue Mountain Station; Dardanelle; Magazine Mountain; Ola; Rich Mountain Station; Winslow. (Young in several stages at Mena and Rich Mountain.)

Indian Territory: Howe; South McAlester.

This is a very common species in xerophytic upland forests in Arkansas, and probably much of the territory of the adjoining States, ranging from Indiana to Texas.

\section{Melanoplus packardii Scudder.}

Indian Territory: Wilburton.

Texas: Amarillo; Bonita; Clarendon; Quanah; Wichita Falls.

Oklahoma: Cache; Mountain Park; base and summit of Mount Sheridan.

Common among weeds and tall grass, varying greatly in amount of fuscous marking on pronotum and hind femora, as well as in the color of the hind tibir (glaucous, cherry-red, yellow), apparently running into foedus.

\section{Melanoplus palmeri Scudder.}

Texas: Amarillo; Clarendon; Quanah.

Oklahoma: Mountain Park.

A very plentiful species among the weeds and taller grasses of the dry plains. Fresh specimens, with their bright blue or greenish hind 
tibiæ and red femora, are very attractive. The types of palmeri in the Scudder collection are evidently alcoholic material from which all brilliancy of color had departed when described. I have little doubt that the $M$. sanguineus of Bruner (Colo. Agric. Coll. Bull. 94, p. 63) is identical with this species.

\section{Melanoplus plebejus Stål.}

Indian Territory: Caddo; Wilburton.

Texas: Wichita Falls.

This, while a campestrian species, is practically a thicket-dweller, living among the denser growth of grasses and other herbage in moist prairie meadows.

Melanoplus propinquus McNeill-Scudder.

Mississippi: Gulfport.

Common in grassy areas of the Gulf Strip of the Lower Austral coast plain.

\section{Melanoplus regalis Dodge.}

Texas: Amarillo; Quanah.

This handsome species is singularly like Aeoloplus regalis in appearance, nearly equaling it in size, closely resembling it in color and general form, but at once distinguished from it by the non-tuberculate subgenital plate of the male, the dull-pointed valves of the ovipositor of the female, and the cherry-red coloring of the lower sulcus and inner face of the hind femora.

Three examples of each sex were secured among weeds.

\section{Melanoplus robustus scudder.}

Arkansas: Blue Mountain Station; Dardanelle; DeQueen; Eagleton; Magazine Mountain; Mena; Ola; Rich Mountain; Rich Mountain Station; Winslow.

Indian Territory: Caddo Hill; Haileyville; Howe; South McAlester.

Texas: Denison.

Oklahoma: Cache; base and summit of Mount Sheridan.

This robust species is a characteristic inhabitant of woodlands, usually xerophytic, where it hops about among the underbrush with vigorous leaps (see pl. 5, fig. 2). It is very variable in wing-length, but not dimorphic, the tegmina of the male ranging from 12 to $21 \mathrm{~mm}$., of the female from $\mathrm{I}_{3}$ to $24 \mathrm{~mm}$; and also in the color of the hind tibiæ, the distal two-fifths of which range from pale yellow to bright coral-red. Frequently, especially in examples with yellow tibiæ, all infuscation distad of the basal pale annulus is lacking except on the tips of the spines. 
Melanoplus scudderi Uhler.

Arkansas: Blue Mountain Station; Dardanelle; Fayetteville; Magazine Mountain, 2,000-2,600 feet; Ola; Van Buren; Winslow.

Indian Territory: Caddo; Howe; South McAlester; Wilburton.

Texas: Myra.

Oklahoma: Cache; Shawnee; base and near summit of Mount Sheridan.

A locally common, even abundant, and very widely distributed species, found in a considerable variety of habitats, either in shrubbery, edges of woodlands, near thickets, or even grasslands.

"Two males from Bonita, Texas, which I refer to this species with some doubt, possess exceptionally broad cerci, the depth nearly or quite equaling the length, the lower margin very strongly convex. To this form I have provisionally applied the name latus." (Psyche, XIII, I22, 1906.)

\section{Melanoplus strumosus Morse.}

Georgia: Sand Mountain.

Alabama: Lookout Mountain.

This species, discovered in Florida and South Carolina on the first trip, proves to be more widely distributed than was thought at that time, reaching the Upper Austral zone and an altitude of $I, 600$ feet or more. At Sand Mountain it was not uncommon among the undergrowth of shrubs and herbage in the forests; at this time (July 8) the young greatly outnumbered the adults.

\section{Melanoplus tepidus Morse.}

Melanoplus tepidus. Psyche, xII, 121, 1906.

Mississippi: Meridian. Three males, three females.

"This species most closely approximates $M$. obovatipennis, agreeing with it in size and general coloration, but may be distinguished from it by the following characters: The subgenital plate of the male feebly but distinctly tuberculate subapically; the upper valves of the ovipositor of the female narrower at base in side view; the pronotum is more elongate and slightly inflated, its sides and top slightly convex instead of straight, its lateral lobes less deep, and the longitudinal fuscous stripe thereon broader anteriorly, of nearly equal width throughout, covering one-half or more of their depth; the tegmina are slightly more elongate, the eyes of the male are large and very prominent, and the vertex of the head narrower, more prominent, and rather deeply sulcate."

\section{Melanoplus tribuloides Morse.}

Melanoplus tribuloides. Psyche, xIII, 121, 1906.

Alabama: Cheaha Mountain; Turnipseed's Ranch. 
"Similar to $M$. tribulus, but with the digits of the furcula much wider and longer, flattened, from enlarged bases, in length equaling or exceeding the middle breadth of the cerci; the cerci narrower in the middle."

\section{Melanoplus tuberculatus Morse.}

Melanoplus tuberculatus. Psyche, XIII, 121, 1906.

Texas: Quanah; Wichita Falls.

"A rather small, inconspicuous species, long-winged, flavescent brown in color, with unspotted tegmina, faintly barred hind femora, and very pale yellowish-green hind tibiæ. Fuscous stripe of the lateral lobes of the pronotum restricted to the prozona, brownish, sometimes obsolete. Subgenital plate of the male seen from above smoothly rounded posteriorly, its ventral outline from the side smoothly convex, terminating posteriorly in an upwardly directed, acute, subapical tubercle, the lateral margins ampliate at base. Last dorsal segment of abdomen of male emarginate at origin of furcula, the latter consisting of a pair of short, triangular, flattened processes from expanded bases on the segment, scarcely as long as the segment, parallel, and widely separated. Cerci short, but little longer than their basal width, wide and very stout at base, tapering rapidly, the apical half subequal, tapering to a rounded apex, bent strongly upward and inward, the apex flattened and a little reflexed. Tegmina a little surpassing (male) or about reaching (female) the hind knees.

"Body: male, I8-22; female, r9-27. Tegmina: male, 14-18; female, I6-I9. Hind femora : male, II-I2; female, I3-I5 mm."

Phoetaliotes nebrascensis Thomas.

Indian Territory: Caddo; Wilburton.

Texas: Amarillo; Clarendon.

Oklahoma: Cache; base of Mount Sheridan.

A common campestrian species among the dense grass of the plains and prairies. The young are often largely dull ivory-white in color and present a very singular appearance with their absurdly large heads. It matures late; the young in various stages were met with at Caddo on August 8, and were still plentiful at Wilburton three weeks later.

\section{Paroxya atlantica Scudder.}

Mississippi: Biloxi (juv. 4, 5) ; Gulfport (juv. 5) ; Nugent (juv. 3, 4, 5).

Common in the piney-woods of the Gulf Strip of the Coastal Plain, especially in grassy places among the inkberry or myrtle shrubbery (Ilex glabra), and also in swampy spots and sometimes in the saltmarshes (p1. 2, fig. 2). 
Paroxya floridiana Thomas.

Mississippi: Biloxi; Nugent (juv. 5).

Louisiana: Buras (juv: 5-probably this species).

This locust inhabits the tall, upright growth of rushes and other water-plants at the edges of the marshes, ponds, and tidal inlets, and is found at some distance inland in wet meadows,

A single female of this genus, not identifiable with certainty, but belonging either to this species or the next, was taken at Ashdown, Arkansas. Prolonged search for the male or additional examples was tunavailing.

\section{Paroxya hoosieri Blatchley.}

Louisiana: Milneburg.

A single very large male was captured at the edge of the swamp. Its measurements are as follows: Length, 26; hind femora, I6; tegmina, 12 ; antenna, 17 ; pronotum, $5.5 \mathrm{~mm}$.

\section{Dactylotum pictum Thomas.}

Texas: Quanah.

Oklahoma: Mountain Park.

About 30 specimens of this gaily decorated species were secured. These were found crawling sluggishly about in the mesquite grass of the dry prairies, and made little effort to escape when disturbed. Oddly enough, though brightly colored and strikingly marked, this locust is by no means conspicuous on its natural background, and readily escapes notice, except at very close range or while in motion. 


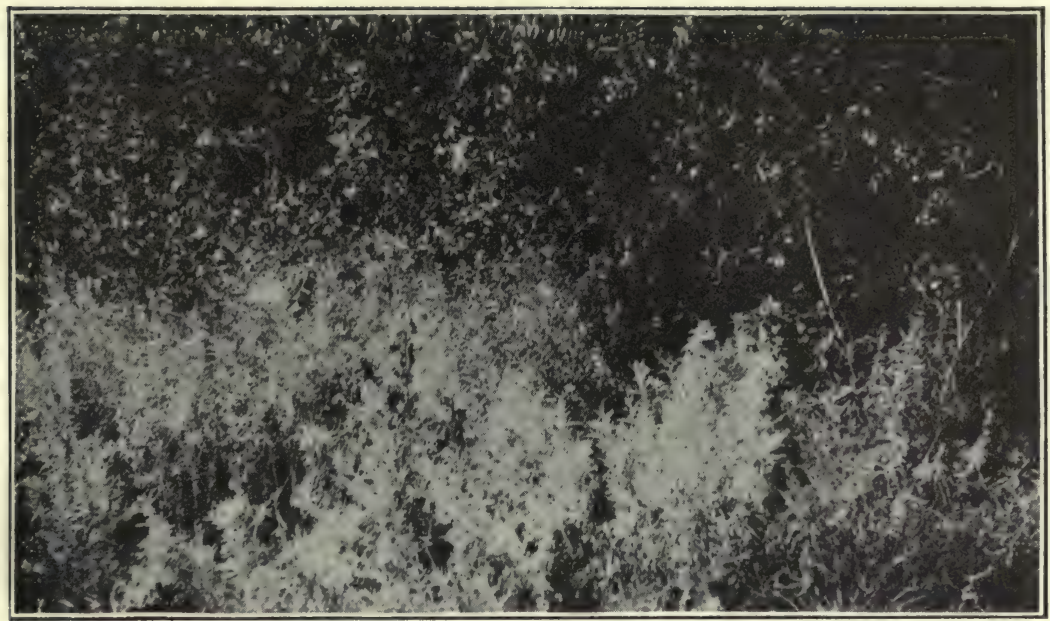

FrG. 1.-White sage (Artemisia sp.) habitat of Hypochlora alba. Wichita Falls, Texas.

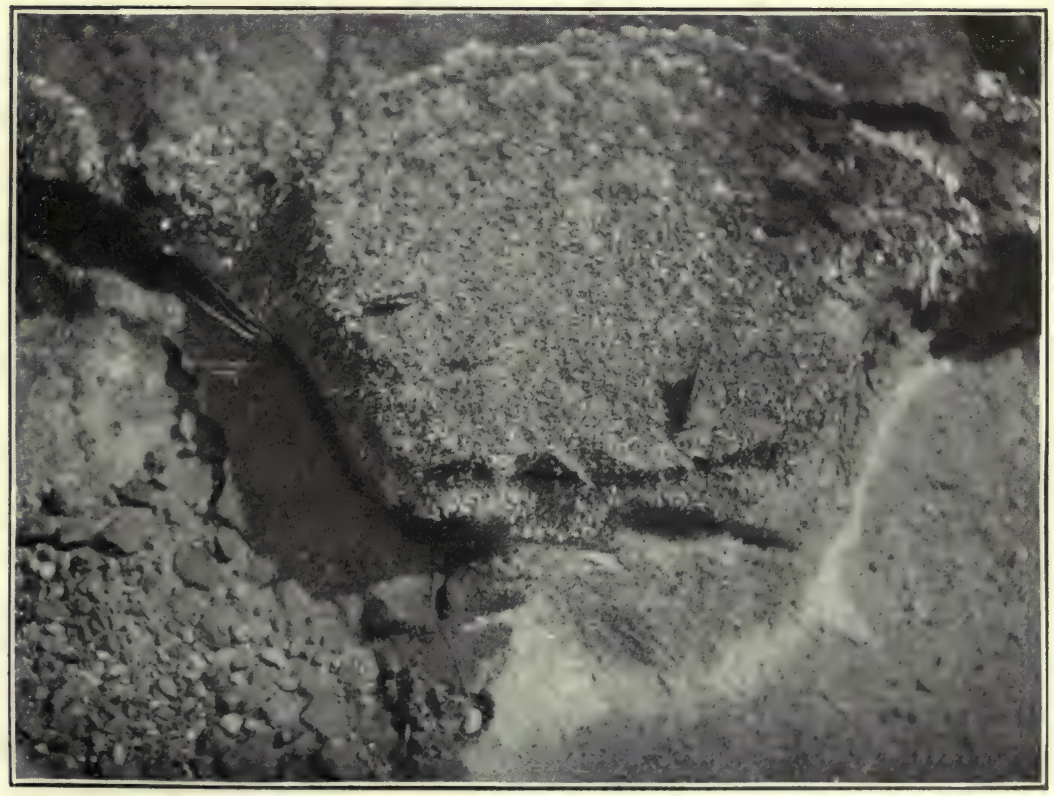

FIG. 2.-Trimerotropis saxatilis-five examples on lichened rock surface.

Sand Mountain, Georgia.

ILLUSTRATING PROTECTIVE COLORATION. 



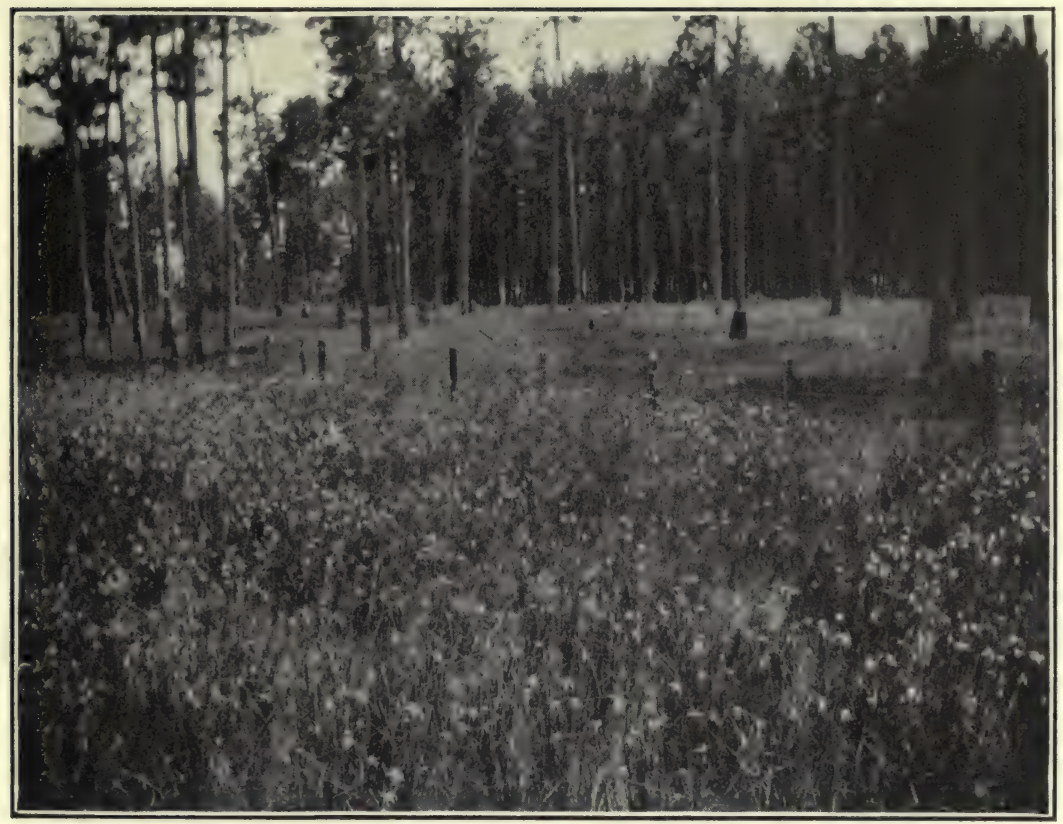

FIG. I.-Swampy spot in pine woods at Nugent, Mississippi. Habitat of Leptysma marginicollis, Mermiria bivittata, Clinocephalus elegans.

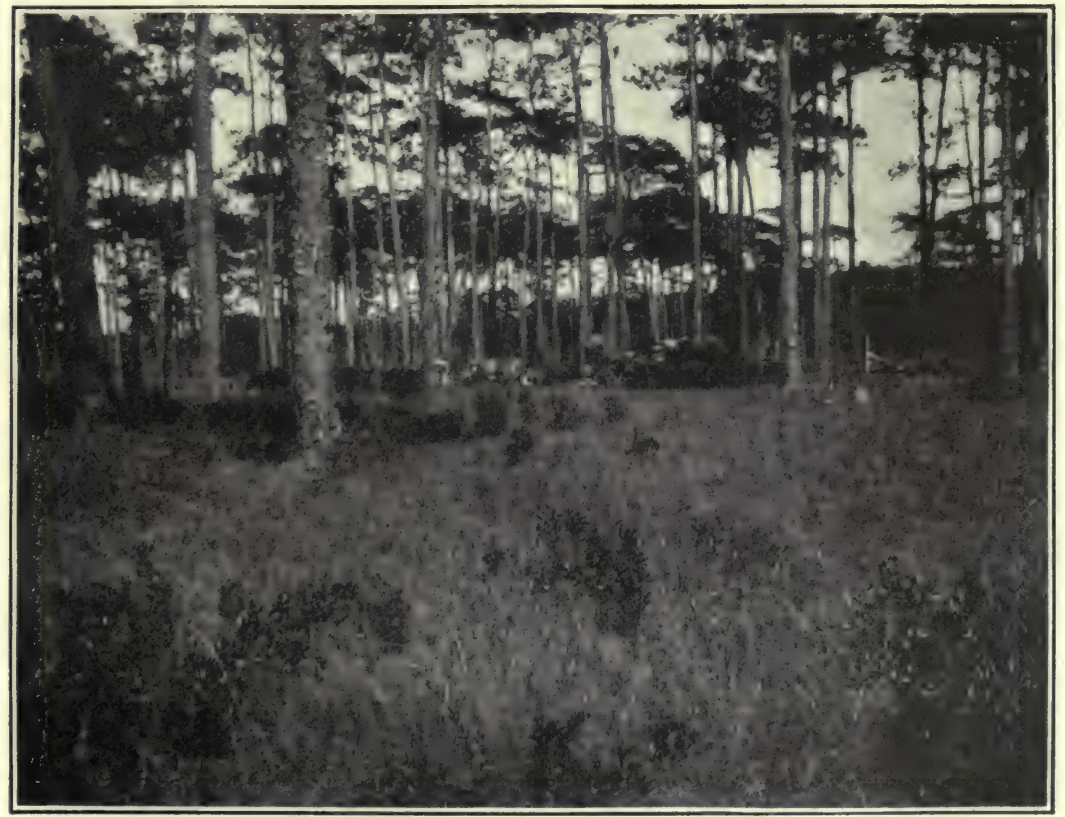

FIG. 2,-Habitat of Paroxya allantica at Biloxi, Mississippi. (Eight-ox log-team returning inland with feed.) 



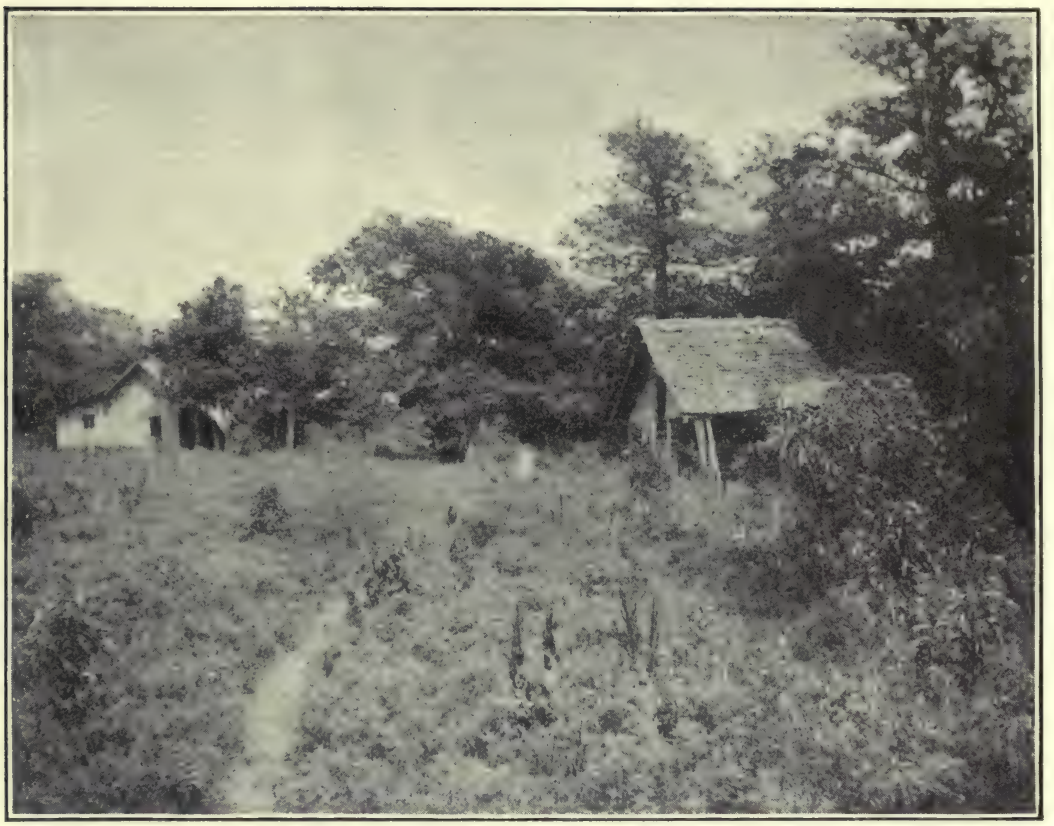

FIG. 1.-Campestrian habitat of Melanoplus femur-rubrum and M. atlanis on abandoned'farm on summit of Rich Mountain, Arkansas.

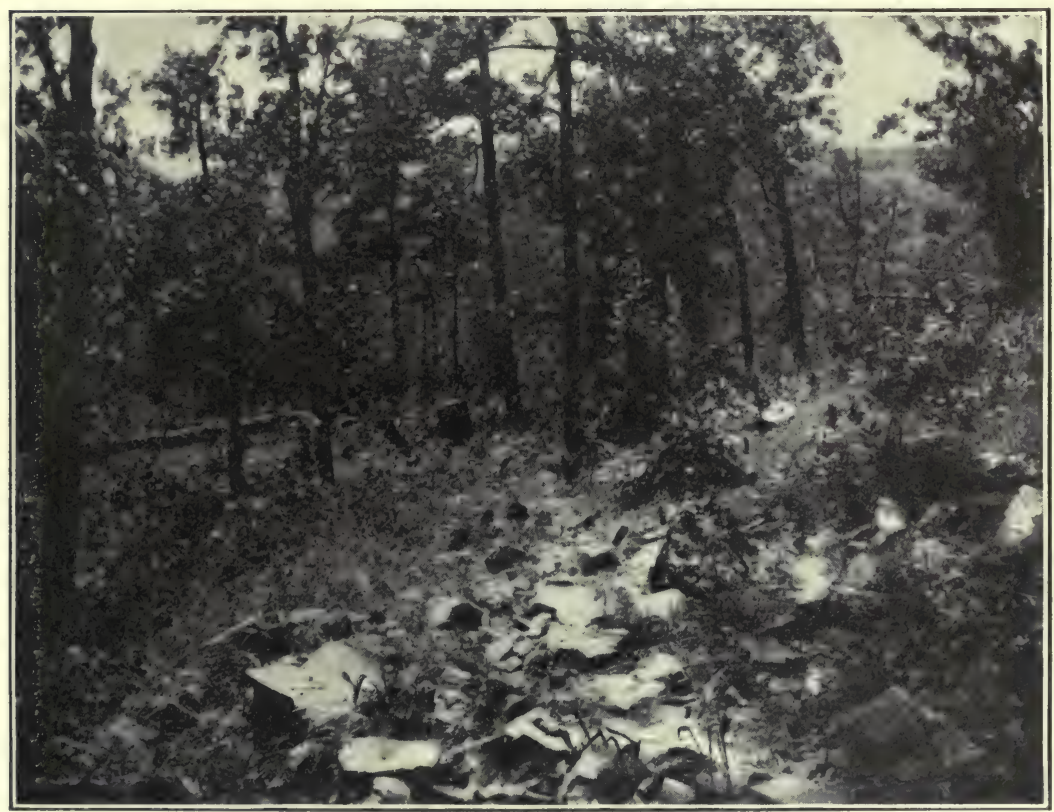

FIG. 2.-Xerophytic forest habitat of Boöpedon auriventris, Paratylotropidia brunneri, Melanoplus scudderi, $M$. robustus, and $M$. obovatipennis on southeast exposure of foothills of Rich Mountain, Mena, Arkansas. 



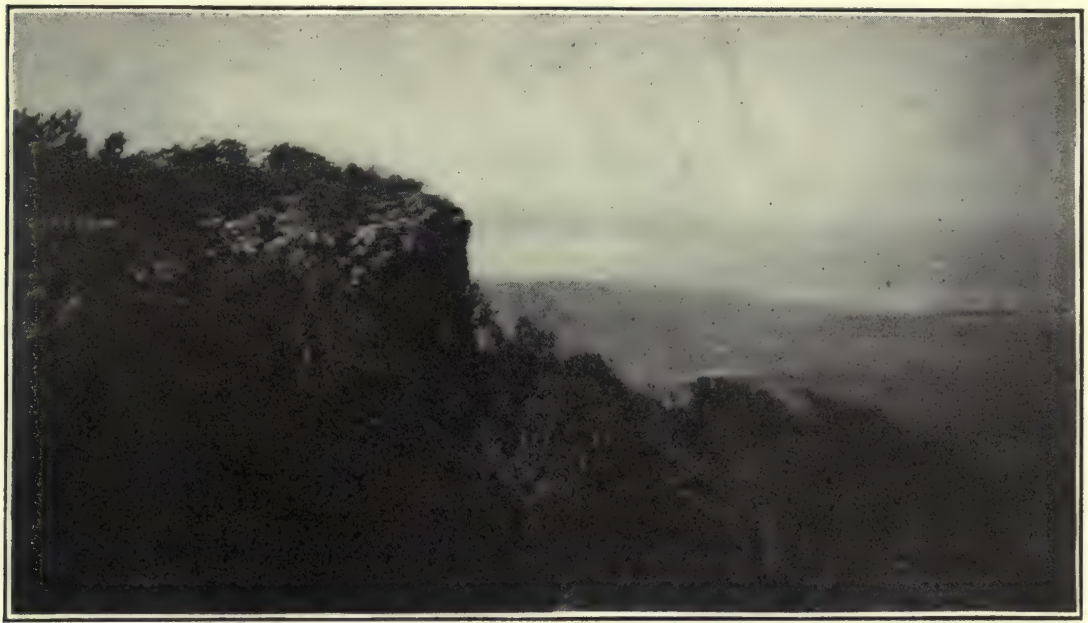

FIG. I.-Escarpment rim ledge habitat of Trimerotropis saxatilis, Magazine Mountain, Arkansas. (Looking northwest over Arkansas River Valley.)

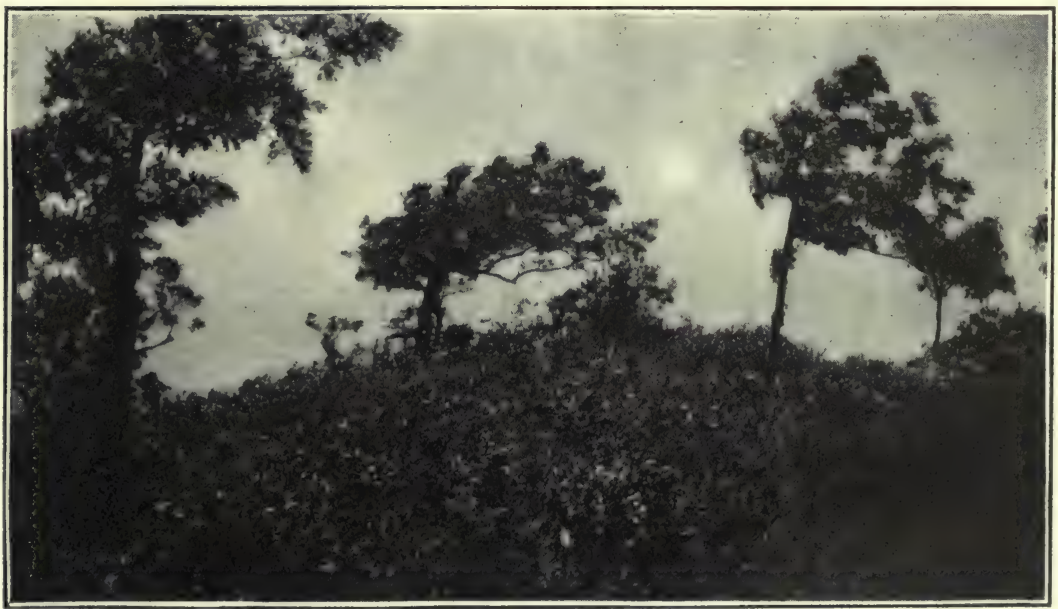

FIG. 2.-Marginal thicket at west end of summit of Magazine Mountain. ARKANSAS MOUNTAIN HABITATS. 



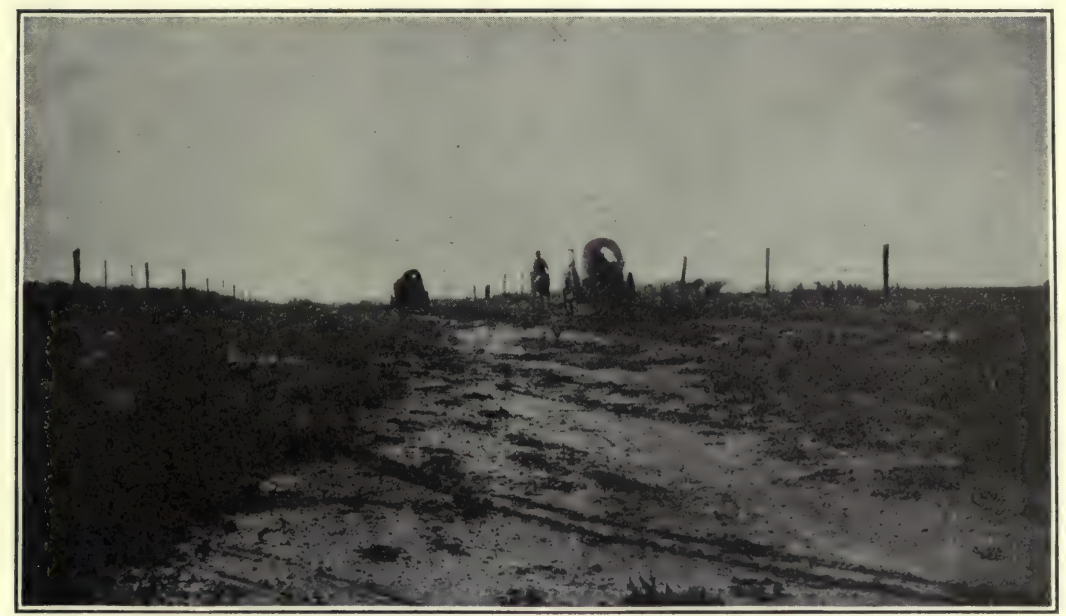

FIG. I.-Roadsides. Habitat of Spharagemon aequale, Trimerotropis lalifasciata, T. citrina, T. vinculata, Hadrotettix trifasciatus, Dissosteira spp., and Hippiscus spp. Wichita Falls, Texas.

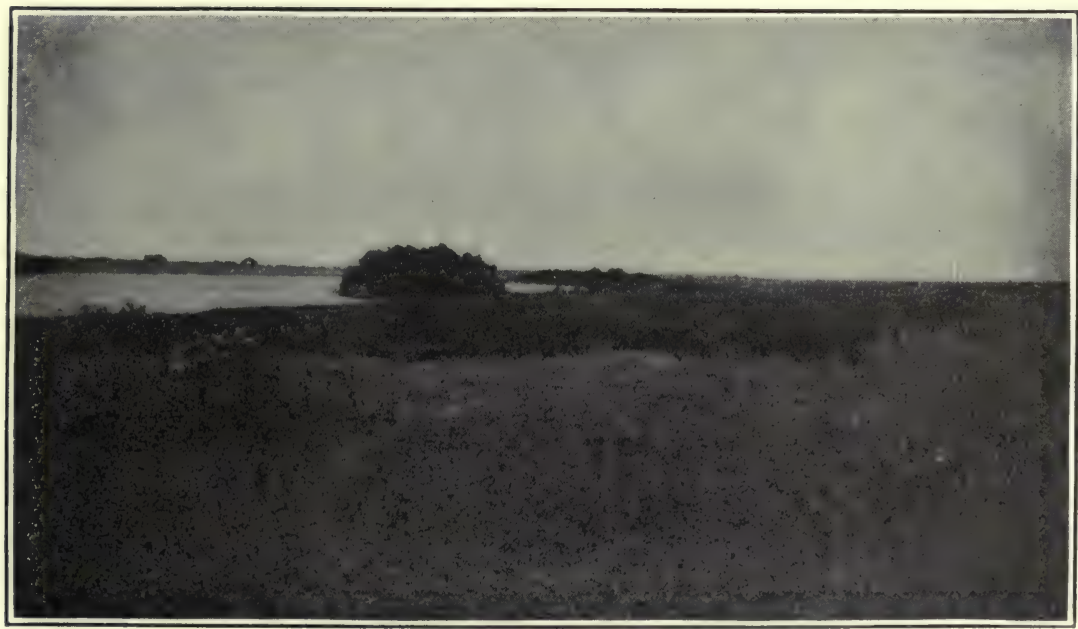

FIG. 2.-Fields. Mesquite grass; Euphorbia and ragweed. Habitat of Opeia obscura, Amphitornus bicolor, Phlibostroma quadrimaculatum, etc. Wichita Falls, Texas. 



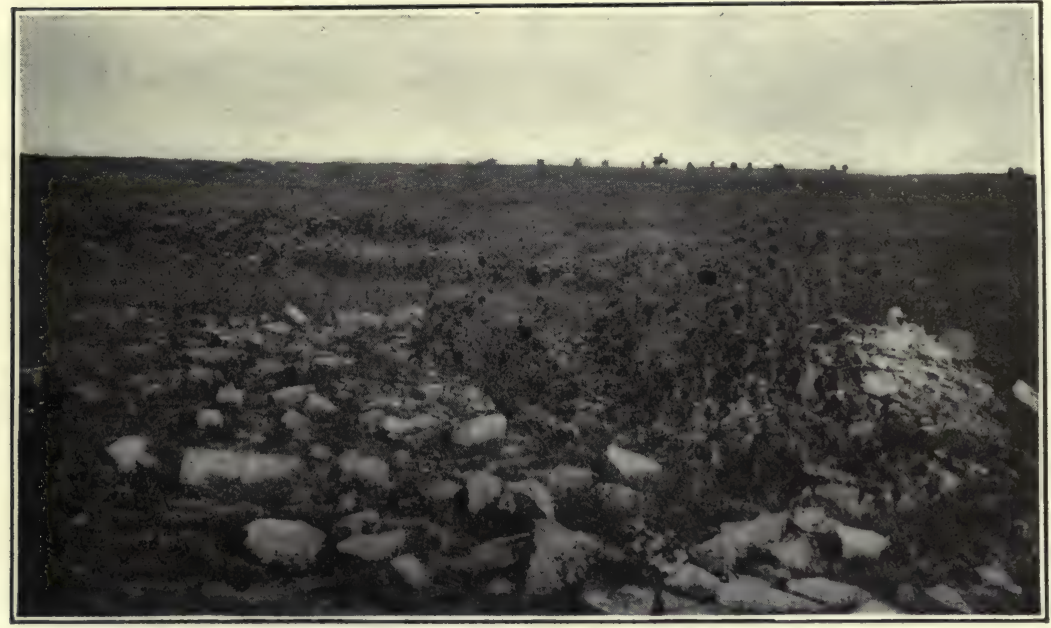

FIG. I.-Stony ground. Habitat of Leprus wheeleri and Hadrotellix trifasciatus. Quanah, Texas.

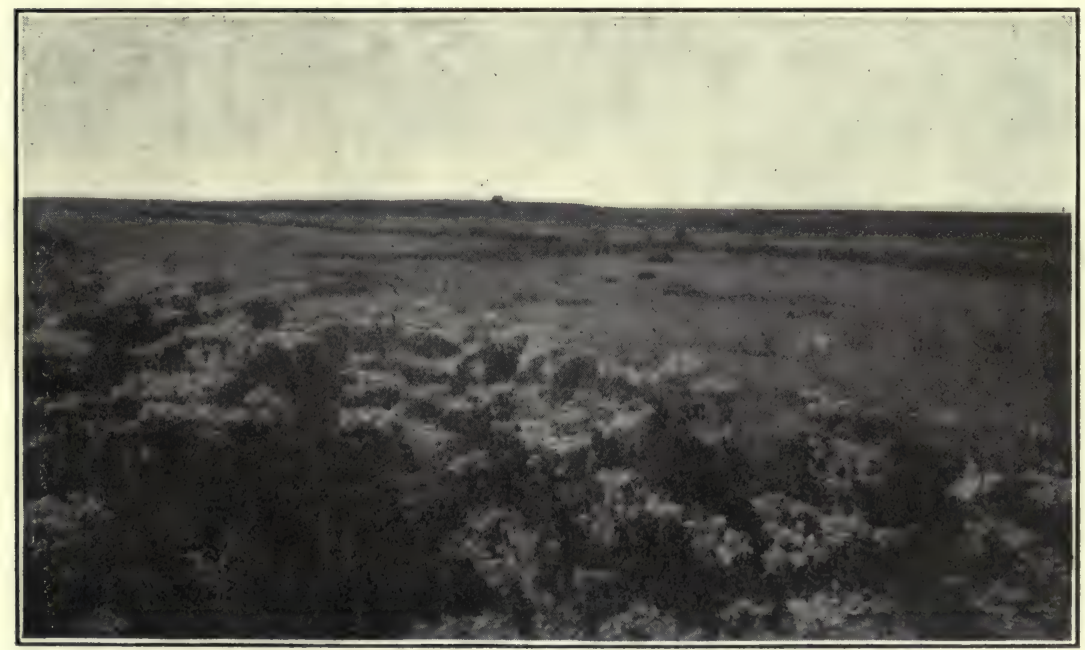

F1G. 2,-The Llano Estacado at Amarillo, Texas. Weeds on old road-plowing. PRAIRIE-PLAINS AND PLAINS HABITATS. 



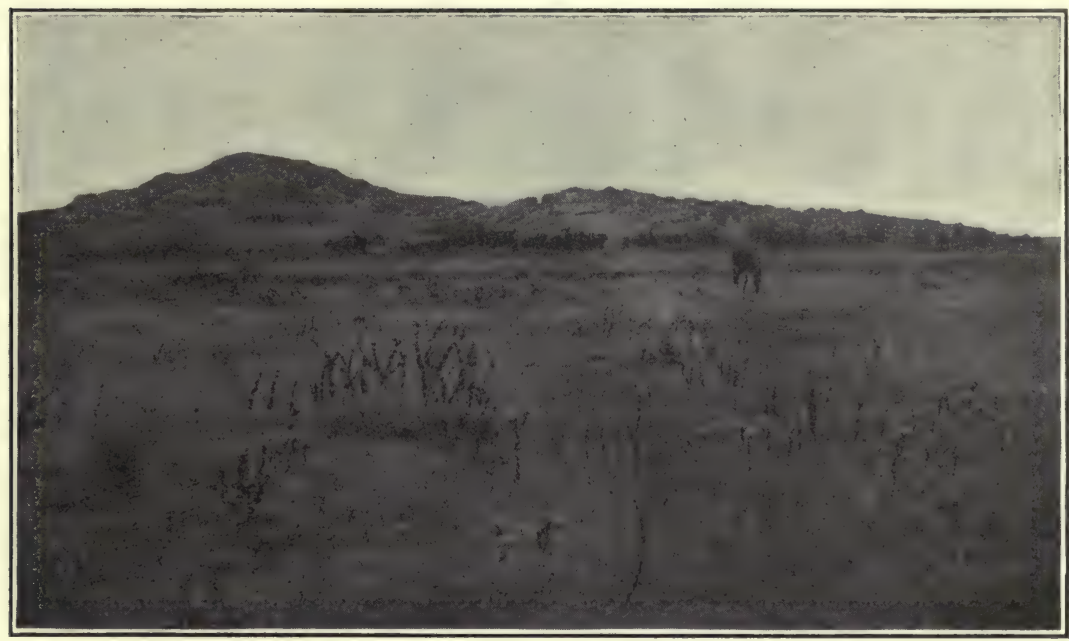

FrG. I.-Prairie-plains and outlying rocky spur of Wichita Mountains at Mountain Park, Oklahoma.

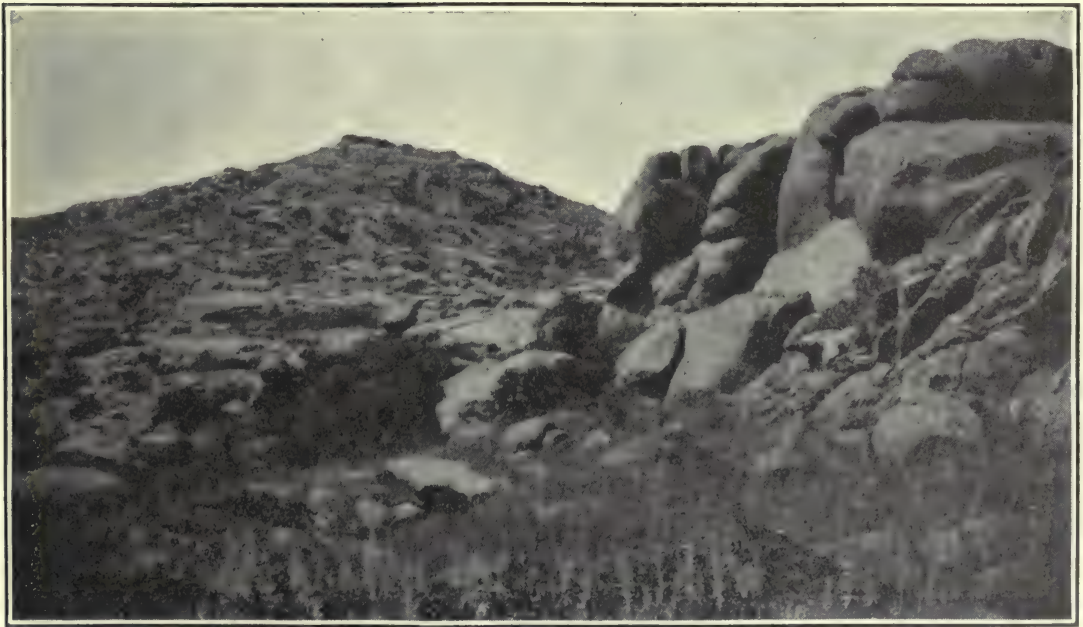

Fre. 2,-View on spur shown in fig. I. Bunch-grass and ledge habitats. Mermiria spp., and Trimerotropis saxatilis.

WICHITA MOUNTAIN DISTRICT. 



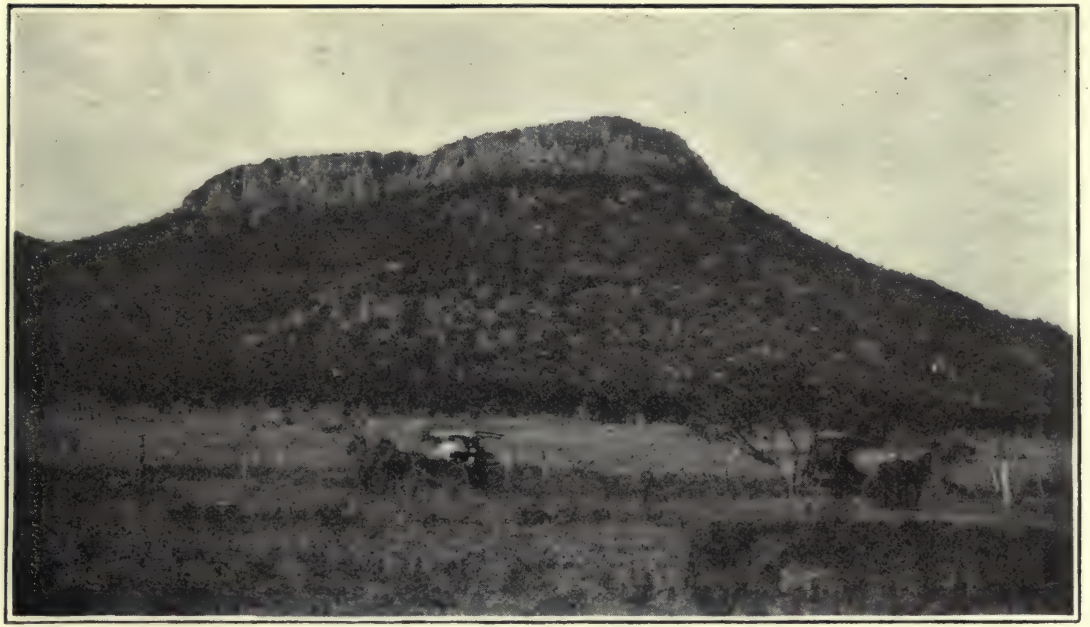

FIG. 1. Mount Sheridan, from the east base. Field, forest, and ledge habitats. (Also in the following three views.)

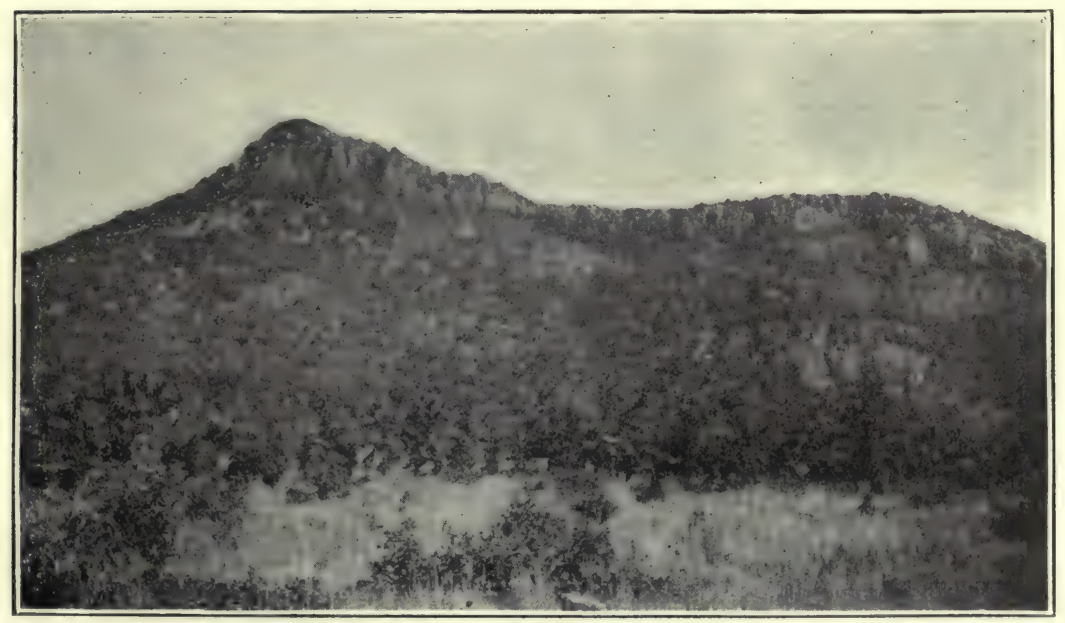

FiG. 2.-Mount Sheridan, from the north. WICHITA MOUNTAIN DISTRICT. 



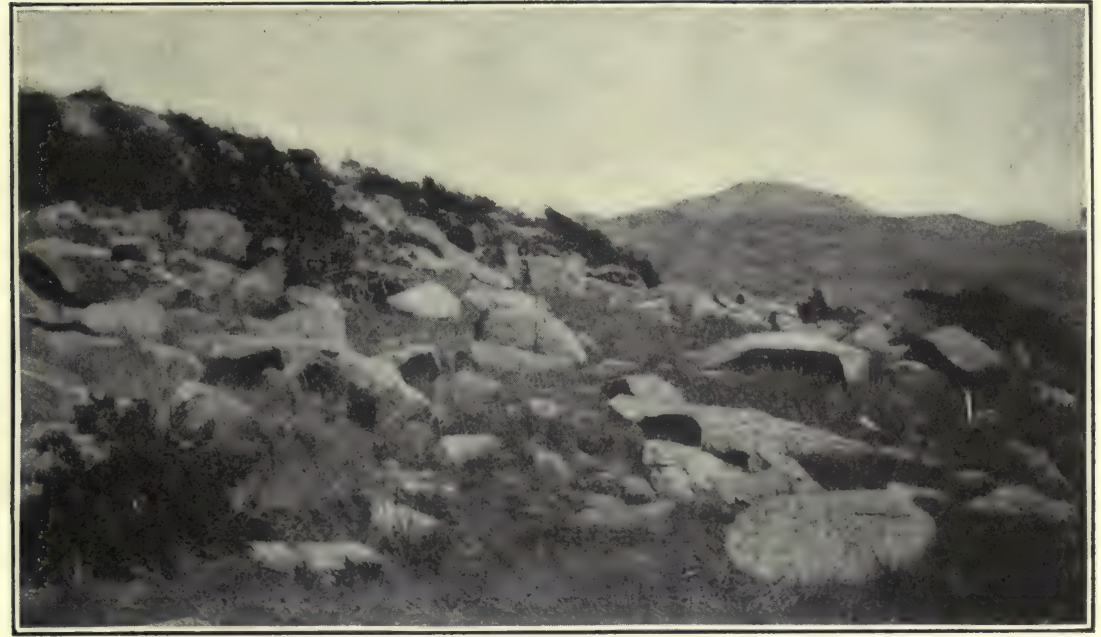

FrG. 1.- Summit of Mount Sheridan, looking east to Mount Scott.

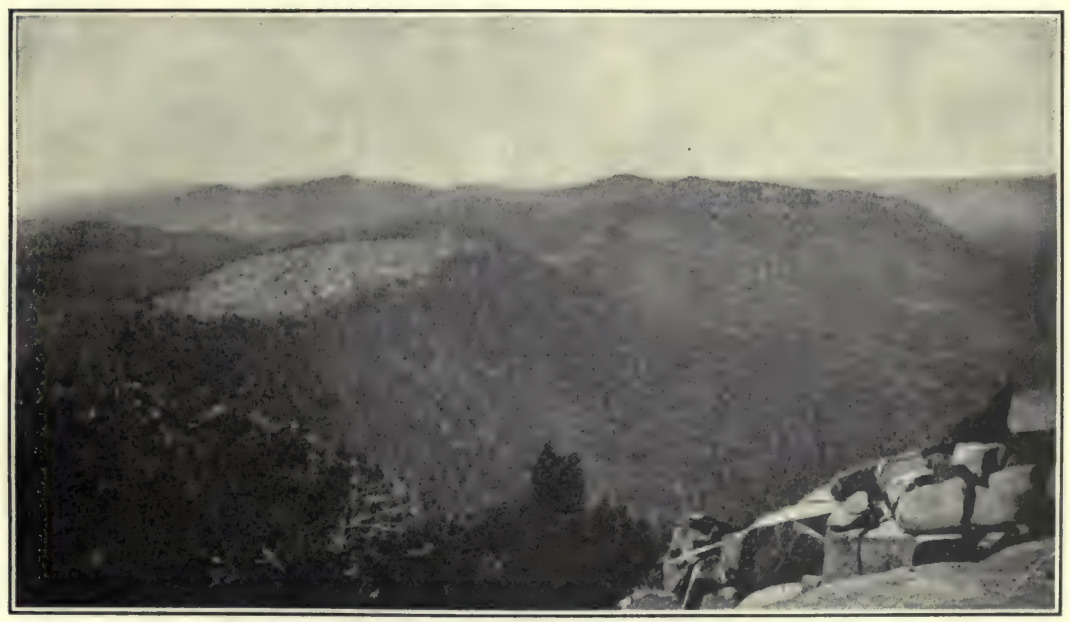

FIG. 2.-Summit of Mount Sheridan, looking northwest.

WICHITA MOUNTAIN DISTRICT. 





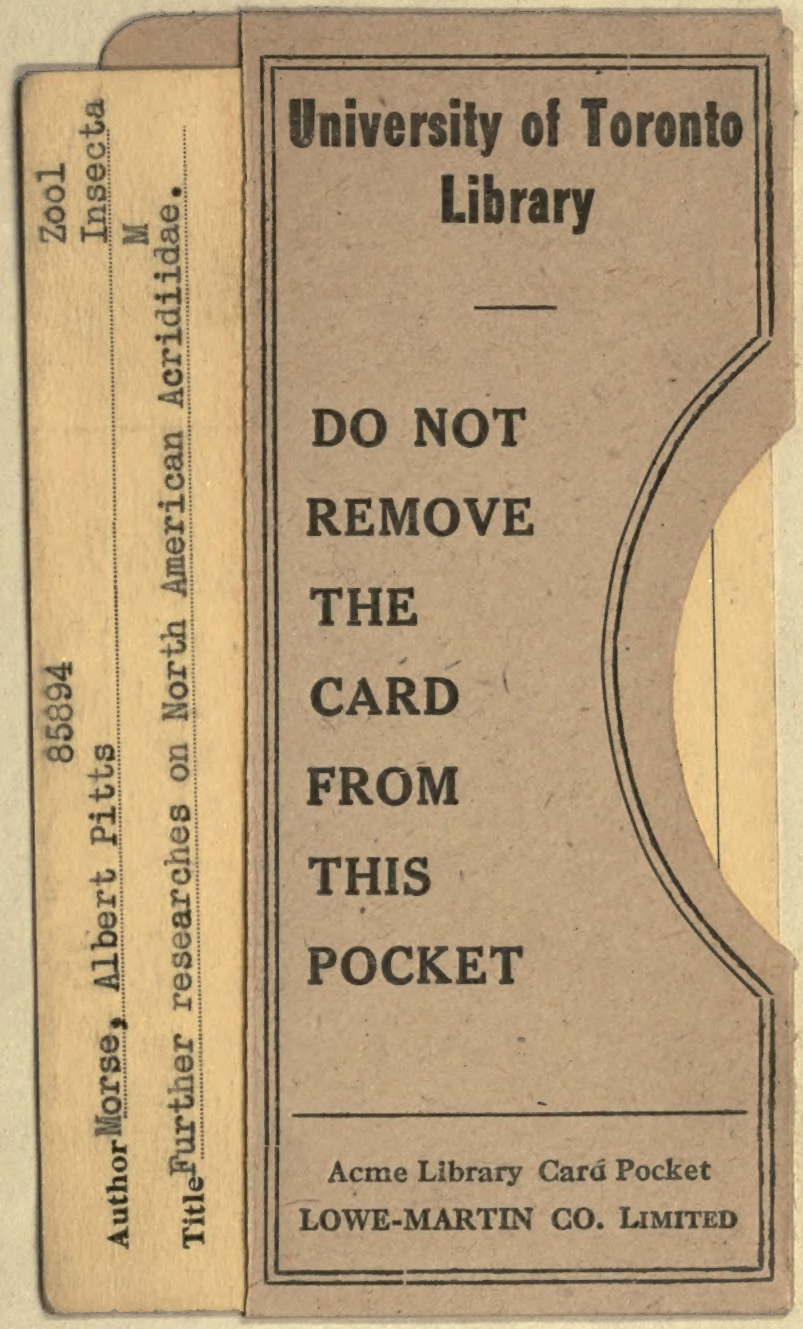


